NBER WORKING PAPER SERIES

\title{
TAXES AND GROWTH IN A FINANCIALLY UNDERDEVELOPED COUNTRY: EVIDENCE FROM THE CHILEAN INVESTMENT BOOM
}

\author{
Chang-Tai Hsieh \\ Jonathan A. Parker \\ Working Paper 12104 \\ http://www.nber.org/papers/w12104 \\ NATIONAL BUREAU OF ECONOMIC RESEARCH \\ 1050 Massachusetts Avenue \\ Cambridge, MA 02138 \\ March 2006
}

We thank Daron Acemoglu, Robert Barro, Ben Bernanke, Bruce Preston, Ricardo Caballero, Angus Deaton, J. Bradford DeLong, Erica Field, Christian Julliard, Peter Klenow, Jose Scheinkman, Fabio Schiantarelli, Christopher Sims, James Tybout, and Rodrigo Valdes for helpful comments. We thank Dani Rodrik's project on analytical country studies on economic growth for partial funding. Parker acknowledges the Sloan Foundation and NSF grant SES-0096076 for financial support. Hsieh thanks the research committee of the World Bank for financial support. Erica Field provided excellent research assistance. This paper formerly circulated as "Taxes and Growth in a Financially Underdeveloped Country: Explaining the Chilean Investment Boom." The views expressed herein are those of the author(s) and do not necessarily reflect the views of the National Bureau of Economic Research.

(C2006 by Chang-Tai Hsieh and Jonathan A. Parker. All rights reserved. Short sections of text, not to exceed two paragraphs, may be quoted without explicit permission provided that full credit, including (C) notice, is given to the source. 
Taxes and Growth in a Financially Underdeveloped Country: Evidence from the Chilean Investment Boom

Chang-Tai Hsieh and Jonathan A. Parker

NBER Working Paper No. 12104

March 2006

JEL No. H32, E22, D92, O54, O16

\begin{abstract}
$\underline{\text { ABSTRACT }}$
This paper argues that taxation of retained profits is particularly distortionary in an economy with good growth prospects and poorly developed financial markets because it primarily reduces the investment of financially constrained firms, investment that has marginal product greater than the after-tax market real interest rate. Contrarily, taxes on distributed profits or capital gains primarily reduce the investment of financially unconstrained firms. Chile experienced a banking crisis over the period from 1982 to 1986 and in 1984 reduced its tax rate on retained profits from 50 percent to 10 percent. We show that, consistent with our theory, there was a large increase in aggregate investment after the reform which was entirely funded by an increase in retained profits. Further, we show that investment grew by more in industries that depend more on external financing, according to the Rajan and Zingales (1998) measure. Finally, we present some weak evidence from comparisons of investment rates across firms for several different measures of their likelihood of being financially constrained.
\end{abstract}

Chang-Tai Hsieh

Department of Economics

University of California, Berkeley

549 Evans Hall, \#3880

Berkeley, CA 94720-3880

and NBER

chsieh@econ.berkeley.edu

Jonathan A. Parker

Department of Economics

416 Robertson Hall

Princeton University

Princeton, NJ 08544-1021

and NBER

jparker@princeton.edu 


\section{Introduction}

The performance of the Chilean economy since the mid 1980s has been extraordinary: Chile's GDP per capita grew at an average rate of 4.5 percent per year during the decade following 1983 (Figure 1a). While not as impressive as the growth miracles of the Asian developing economies during the postwar period, Chile's strong economic performance is unique among the developing economies in the Western hemisphere. As is well known, an important part of Chile's impressive growth is a saving and investment boom on the order of ten percent of GDP (Figure $1 b$ ). In this paper, we present evidence that a main cause of this investment and growth boom was a corporate tax reform that cut the tax rate on retained profits from nearly 50 percent to 10 percent over the period 1984 to 1986.

From economic theory, we argue that this reform could have large effects. When firms face credit constraints, taxation of retained profits is more distortionary than taxation of dividends or household capital gains. By definition, the return to the marginal investment of a constrained firm is (weakly) greater than the after-tax real interest rate. Taxation of retained profits reduces precisely this potentially highly productive investment, since it reduces internal funds and therefore reduces the investment of constrained firms by the amount of the tax. Unconstrained firms can largely avoid retaining profits and are able to fund investment through other means. Thus, in an economy with poorly developed financial markets, but otherwise favorable macroeconomic policies and conditions, such as Chile in the mid $1980^{\prime} s$, taxing retained earnings is potentially quite harmful. ${ }^{1}$ The 1984 tax reform, by reducing the tax rate on retained earnings, increased the internal funds of many credit constrained firms and so may have been responsible for the increase in aggregate investment.

We present three types of evidence to assess the importance of our theory.

First, we show that the timing of aggregate saving and investment boom and its composition are both consistent with the reduction in the taxation of retained profits being a major cause of the investment boom. Investment increased by 4.5 percent of GDP in the first year of the reform and had increased by over 10 percent of GDP by

\footnotetext{
${ }^{1}$ These 'favorable macroeconomic policies' represent other important causes of growth that we discuss subsequently.
} 
five years after the reform, reaching 25 percent of GDP. The tax reform occurred at the beginning of the investment boom while other reforms such as trade liberalization and the privatization of the public pension system significantly predate the boom. More importantly, the increase in investment was entirely funded by business saving, that is, by retained profits. Private saving and public saving remained largely unchanged.

Second, the cross-industry pattern of investment is also consistent with our theory. Using an annual Chilean survey of plants that covers all Chilean manufacturing plants with more than 10 employees, we show that investment rates rose after the reform primarily in industries that are heavily dependent on external finance. Industries classified by Rajan and Zingales (1998) as dependent on external finance had larger increases in investment in 1985, 1986 and 1987, although not in the first year of the reform, 1984.

Finally, despite not having clean measures of financial constraints at the firm level, we present the results of comparing the investment rates of plants that are plausibly constrained to those that are plausibly unconstrained using the measures we do have. That is, we divide plants into those that are owned by firms that are more and less likely to face financing constraints and compare the investment behavior of plants owned by these different types of firms through the tax reform. Here, the evidence on our theory is weaker and more mixed. Specifically, we find that the plants owned by firms that exhibited a high correlation of cash flow and investment before the reform increased their investment significantly more in the reform and to some extent following the reform as compared to similar plants that had low prior correlations of cash flow and investment. We also find some evidence that plants owned by firms that previously had low short-term reserves increased their investment more during and to some extent following the reforms. However, we find no evidence that plants owned either by firms that pay rent or by firms that are smaller benefitted disproportionately from the reform, but we also note that the small firm versus large firm distinction is less likely to measure the degree of financial constraints facing a firm in Chile, as compared to the United States.

This paper is primarily related to two literatures. First, our analysis adds to the literature on the impact of tax policies on investment and the importance of financial 
constraints for investment. ${ }^{2}$ Calomiris and Hubbard (1995) and Rajan and Zingales (1998) are the closest papers to our current paper. Calomiris and Hubbard (1995) use a firm's reaction to the retained profits tax of 1936 - 37 in the United States to identify liquidity constrained firms and then study their subsequent investment behavior. We reverse this process. Rajan and Zingales (1998) examine the growth pattern of industries with differing needs for external financing in countries with different levels of financial development. We compare the response of investment to Chile's 1984 tax reform across industries with differing needs for external financing.

Second, we add to the literature on the causes of economic development, and in particular, to the work that has focussed on the Chilean 'miracle.' While the 1984 tax reform is frequently mentioned among Chilean observers as potentially important in explaining the subsequent investment boom, ${ }^{3}$ previous research has focused on other reforms undertaken by Chile, particularly the liberalization of the trade regime, the liberalization and deepening of financial markets, bankruptcy reform, and the privatization of public pension system, rather than on the corporate tax reform as the underlying cause of Chile's growth performance. ${ }^{4}$ To be clear, our argument is not that these other reforms are irrelevant for growth in general. It is likely that some of these reforms raised Chile's steady-state level of output per person, although we do not evaluate this claim. We provide evidence that the reduction in the tax on retained profits increased the accumulation of capital, and our preferred interpretation of this finding is that the tax reform lead to rapid rather than slow convergence towards steady-state. In applying this lesson to financially underdeveloped economies more broadly, it is important to note that taxing retained earnings is highly distortionary only when there are productive investment opportunities.

\footnotetext{
${ }^{2}$ See Hubbard (1998), Bernanke and Gertler (1995), Bernanke, Gertler, and Gilchrist (1999), and Hasset and Hubbard (2002) for reviews. Cummins, Hassett and Hubbard (1996) discuss the difficulties inherant in cross-country estimation of the impact of taxes on investment, and present evidence that investment responds to tax incentives in general.

${ }^{3}$ See Agosin (1999), Agosin, Crespi, and Letelier (1997), Budnevich and Jara (1997), Bustos, Engel, and Galetovic (1998), Larroulet (1987), and Marfan and Bosworth (1993) for brief discussions of the 1984 tax reform.

${ }^{4}$ See Bergoeing, Kehoe, Kehoe and Soto (2002), Edwards (1996), Gallego and Loayza (2000), Morandé (1996), and Pavcnik (2002).
} 
The outline of the paper is as follows. The next section models the effect of taxes on retained profits when some firms are constrained from borrowing as much as they would like to invest at market interest rates. Section 3 describes the 1984 tax reform in Chile. Section 4 present aggregate evidence that the corporate tax reform was a significant cause of Chile's rapid growth. Sections 5 details our use of the annual plant-level data from the Chilean manufacturing census that we use in sections 6 and 7 to test the industry and plant-level predictions of our theory respectively. Section 8 discusses alternative explanations for Chile's investment boom, and in doing so provides some broader description of the Chilean experience for the reader. A final section concludes and an Appendix contains additional theoretical results and information about the data that we employ.

\section{Investment and taxes on retained earnings}

How does a tax on retained profits alter investment and productivity? In this section, we consider the investment decision of a household that owns a profitable firm and is unable to borrow to finance investment. Firms and households face credit constraints and firms with highly productive investment opportunities are constrained from borrowing to invest at the optimal rate. We consider an economy like Chile's in which there are three taxes levied on capital income: profits tax $\left(\tau_{p}\right)$, retained profits tax $\left(\tau_{r}\right)$, and dividend income $\operatorname{tax}\left(\tau_{d}\right)$. The retained profits and the dividend income tax rate are defined as the tax rate net of the profits tax. We assume that the economy is small and open so that the after-tax real interest rate is fixed at $r^{f}$.

Consider two firms that have the same initial capital stock $\left(K_{0}\right)$ and profits $(\pi)$, but that differ in the productivity of the investment opportunities available to them. Firm $H$, has a highly productive investment opportunity, and firm $L$ does not. Figure 2 shows the marginal product of capital in the future for each firm, with $M P K^{H}$ lying above $M P K^{L}$. In a world with perfect capital markets, each firm would set the pre-tax marginal product of capital equal to the required pre-tax rate of return to investment, which is equal to the after-tax rate of return adjusted for the tax rates. Thus the first-best levels of capital chosen would be $K^{H *}$ and $K^{L *}$ and gross investment would equal $K^{H *}+K^{L *}-2(1-\delta) K_{0}$ 
where $\delta$ is the depreciation rate of old capital.

However, if we assume that these firms, and their owners, do not have access to external funds - debt or equity - to finance further investment, then their new investment is limited by their after-tax retained profits or $\left(1-\tau_{p}\right)\left(1-\tau_{r}\right) \pi$. Both the profits tax and the tax on retained profits decrease funds available for investment. This bound on investment limits the future capital stock to

$$
\bar{K}=(1-\delta) K_{0}+\left(1-\tau_{p}\right)\left(1-\tau_{r}\right) \pi
$$

Thus, as shown, firm $H$ with a highly productive investment opportunity is unable to take full advantage of this opportunity $\left(\bar{K}<K^{H *}\right)$.

Consider now a cut in the rate of tax on retained profits to $\tau_{r}^{\prime}$. The new maximum level of the capital stock is

$$
\bar{K}^{\prime}=K_{0}+\left(1-\tau_{p}\right)\left(1-\tau_{r}^{\prime}\right) \pi>\bar{K} .
$$

This tax cut has two important features. First, it impacts firms differently. For the constrained firm $(H)$, every peso decrease in tax revenue leads to a peso increase in its capital stock: $\Delta K=\left(1-\tau_{p}\right) \pi \Delta \tau_{r}=\Delta$ revenue. For the unconstrained firm, the decrease in tax paid does not lead to a corresponding increase in its capital stock.

Second, new investment caused by this policy occurs for projects with productivity that exceeds the marginal product of a peso of outside capital or external funds. It is precisely those firms with the most productive investment opportunities which have the greatest need for funds for capital and so benefit the most from an increase in available internal funds. The policy change thus leads to an increase in productivity. The increase in output from the increase in capital is $\Delta Y=\frac{M P K^{H}(\bar{K})+M P K^{H}\left(\bar{K}^{\prime}\right)}{2} \Delta K>=\frac{r^{f}}{\left(1-\tau_{p}\right)\left(1-\tau_{d}\right)} \Delta K$.

Comparatively, a cut in the dividend tax rate increases the incentive to invest by all firms. But highly profitable firms that are not paying dividends and are cash constrained are unable to raise their investment rates in response to such a tax cut. The marginal product of new investment generated from such a tax cut has the social marginal value of capital since it changes the investment rates of firms that are setting their capital stocks so as to equalize marginal products and interest rates. Alternatively, a cut in the profits 
tax rate increases the incentive to invest by all firms, and allows further investment by cash constrained firms, but does not target the tax cut at highly productive investment opportunities. Similarly, a cut in the household tax on capital gains reduces the frictionless demand for capital but, at the margin, does not reduce the capital demand of constrained firms.

This graphical exposition is stylized in three ways worth noting. First, it is unlikely that any firms are truly constrained. Most if not all firms probably have access to funds at some price. But for many firms the costs of monitoring and enforcement may be extremely high, so that these firms face interest rates far above official rates. Such transaction costs associated with making loans act in a similar way to credit constraints. ${ }^{5}$ Second, we have not been explicit about product markets. It is necessary that the size of unconstrained firms be limited by economies of scope (so there is diminishing returns in $F($.$) ) or by de-$ mand, such as through monopolistic competition. Thus the profit opportunities available to one firm are not available to all firms. If they were, the distribution of internal funds and credit constraints would be irrelevant for aggregate investment. Finally, in a multiperiod world, a tax on retained profits reduces optimal investment for an unconstrained firm. Only for a firm without new investment (in excess of depreciation allowances) is there no tax benefit or government revenue lost and no change in incentives or value. However, the impact remains significantly less than on the investment behavior of a constrained firm because the retained profits tax affects the marginal return to investment from the optimal level rather than a tightening of a binding constraint. ${ }^{6}$

In appendix $A$, we present a two-period model that formalizes the above arguments, and from this simple model we gauge the magnitude of the increase in capital stock that we expect to result from a cut in the tax in retained profits. The aggregate importance of a tax on retained profits depends on whether a significant number of firms are credit

\footnotetext{
${ }^{5}$ As we argue later, in 1984, the Chilean banking sector was still suffering the after effects of the debt crisis. A number of banks had gone bankrupt and a number had been taken over by the government. Thus, at this time, the sector that monitors loans and enforces debt legal debt contracts was small and probably had low technology leading to high costs of external finance.

${ }^{6}$ Although we do not study firm creation, the retained profits tax significantly changes the value of a new firm, and firm creation does increase following the reform.
} 
constrained. As a rough benchmark, suppose that half of the firms (weighted by their ex-post capital stock) in Chile are credit constrained and are investing all their internal funds. The share of profits (before taxes) to value added can be approximated by the capital share of national income net of debt payments and depreciation, which we take to be 20 percent for Chile. ${ }^{7}$ If the tax on retained profits falls from $50 \%$ to $10 \%$, as happened in Chile, then the cash flow available to a firm increases from 10 percent to 18 percent of value-added. If only credit-constrained firms invest the additional cash flow, then a lower bound on the effect of this tax policy change is a 4 percentage point increase in the investment share of $G D P(8 \times 1 / 2)$, which is slightly less than half of the increase in the investment share of $G D P$ in Chile since the mid $1980^{\prime} s$.

In sum, for firms that face liquidity constraints, taxes on retained earnings remove cash from inside credit-constrained firms where it is more valuable.

\section{The 1984-1986 tax reform}

The Chilean tax system prior to 1984 was based upon the principle that households and firms should be treated similarly in the tax code. This principle was implemented by setting the tax rate applied to retained profits of firms equal to that applied to dividends or distributed earnings. That is, the personal and corporate tax codes were structured so that whether profits were paid to the owner or to the firm was irrelevant for tax revenue collected.

More specifically, in the period prior to 1984, the tax treatment of capital income in Chile can be summarized as follows: 1) profits were taxed at a 10 percent rate; 2) retained profits (net of the corporate profits tax) were taxed at either the personal income tax rate of the owners (from 0 to 58 percent) for limited-liability corporations (Sociedad Limitadas) or a 40 percent rate for publicly traded companies (Sociedad Anonimas); 3) dividends (net

\footnotetext{
${ }^{7}$ From 1985 to 1998 , the average capital share was 51 percent and the average capital income net of depreciation was 41.2 percent of GDP (Banco Central de Chile, 1999, Anuario de Cuentas Nacionales, 1999, Table 1.57). Given that this number is larger than the capital share for a typical country and that interest payments typically account for a third of capital share, 20 percent is a conservative estimate of the quantity of interest.
} 
of the corporate profits tax) were taxed at the personal income tax rate (ranging up to 58 percent $){ }^{8} 4$ ) realized capital gains were taxed as dividends if owned by an individual or as corporate profits if owned by a firm. ${ }^{9}$ These taxes cumulate to a high effective tax rate on retained profits. Retained profits of publicly traded companies were first taxed at 10 percent (the corporate profits tax) and the residual net of the 10 percent tax was then taxed at 40 percent, for an effective tax rate of 46 percent on retained profits. The tax treatment of retained profits of limited liability corporations was similar, except that the residual net of the 10 percent corporate profits tax was taxed at the marginal income rate of the owner of the firm. This yields an effective tax rate on retained profits of $0.1+0.9 \tau(\tau$ is the marginal income tax rate of the owner of the firm) for limited liability corporations. In 1980, the average marginal income tax rate of individuals who paid taxes on dividends and retained profits was 43 percent, which translates into a typical effective tax rate of almost 50 percent on retained profits. ${ }^{10}$

In January 1984, the Chilean government enacted a significant tax reform. While the reform altered both the personal and corporate tax codes, the largest change was the nearelimination of the tax on retained profits that had paralleled the tax on dividends. The effective tax on retained profits was lowered to 10 percent, effective immediately for limited liability corporations but phased in over three years for publicly traded companies. ${ }^{11}$ The tax reform did not alter the tax on corporate profits (10 percent) and left the tax treatment of capital gains largely unchanged. ${ }^{12}$ With respect to dividend taxation, the

\footnotetext{
${ }^{8}$ This is the tax rate on dividends of limited liability firms, but the dividends tax for shareholders of publicly traded companies (Sociedades Anonimas) is slightly more complicated. There were two taxes on dividends of publicly traded companies. First, dividends were taxed at 40 percent. Second, dividends net of the 40 percent tax was taxed at the personal income tax rate minus 0.4. The tax rate on dividends (net of the corporate profits tax) is therefore $0.6^{*} \tau+0.16$, where $\tau$ is the personal income tax rate. If the personal income tax rate is 40 percent, the dividends tax rate is equal to the personal income tax rate (and equal to the dividend tax rate for limited liability corporations).

${ }^{9}$ Capital gains on assets held for less than a year were not taxed prior to 1984 .

${ }^{10}$ Calculated from Servicio de Impuestos Internos (1980), pg. 44.

${ }^{11}$ The retained profits tax rate for publicly-traded companies was lowered to 30 percent in 1984,15 percent in 1985, and 0 thereafter.

${ }^{12}$ The 1984 tax reform removed the tax exemption on capital gains held for less than a year, but otherwise did not change the tax treatment of capital gains.
} 
tax reform widened personal income tax brackets and lowered marginal income tax rates slightly. Table 1 describes the personal income tax rates before and after the tax reform. In addition to the cut in income tax rates, the tax reform also provided a credit for corporate taxes paid that reduced the basis for the payment of the dividend tax. Table 2 summarizes the effective tax rate on dividends and retained profits before and after the tax reform.

We note two additional important features of the tax system. First, firms pay estimated taxes on retained earnings monthly. Thus the change in the tax rate on retained profits has an immediate impact on the cash flow of corporations. Second, the corporate tax code was stable from 1986 to 1988, but the tax on retained profits was eliminated entirely for the tax year 1989. Following 1989, the retained profits tax was increased to 15 percent for the remainder of the $1990^{\prime} s$. We focus our analysis of firms on the period $1980-1990$.

It is worth asking how the cut in income tax rates is likely to have impacted the Chilean economy. Cuts in personal tax rates have two main effects on incentives. First, to the extent that the cuts in marginal tax rates on labor income are perceived as highly persistent (as they turned out to be in Chile), then changes in tax rates provide no incentive to substitute labor intertemporally. But persistent tax cuts cause wealth effects that reduce labor supply and substitution effects from leisure to consumption that increase labor supply. Based on observed wage levels and hours of work across countries and over time, if either effect dominates, it is the wealth effect, so that if anything the Chilean reform should have reduces labor supply. This is hardly an alternative explanation for the observed boom in saving. ${ }^{13}$

Second, a reduction in the taxation of dividend income increases the incentive to save and accumulate capital. Might this aspect of the Chilean reform then have caused the observed economic boom? It is unlikely to have played a large role since, as noted in the Introduction, Chile experienced an investment boom at the time of the reform while saving

\footnotetext{
${ }^{13}$ The one caveat to this argument is that lower tax rates on labor income also increase the incentive to accumulate human capital. It is at least possible that the investment boom occurred to take advantage of the higher expected future human capital levels.
} 
rose only slowly following the tax reform. Chile borrowed significantly from abroad until 1988 when saving roughly equalled investment. Given the weak observed link between capital income taxation and economic growth across countries and the small changes that Chile actually implemented at this time, the changes in personal tax rates are unlikely to have significant contributed to the Chilean economic boom.

\section{Aggregate evidence}

The behavior of national saving and investment suggest that the reduction in the taxation of retained profits caused at least part of the rapid growth in Chile. Both saving and investment rose following the reform, from an average rate of 15 percent from 1960 to 1983 , to an average rate of 25 percent in the first half of the $1990^{\prime} s$.

Figure $3 a$ shows that there was a striking change not only in the level but also in the composition of saving at the time of the tax reform. Business saving increased after the tax reform, while private saving and public saving remained largely unchanged. Our theory predicts that saving should rise as firms respond to the reduction in the tax on retained profits by retaining more profits, and importantly that households should not decrease active saving to offset this change. ${ }^{14}$ With respect to investment, the timing of the investment boom also supports our theory. Investment increased by 4.5 percent of $G D P$ in the first year of the reform and increases by over 10 percent of GDP over five years, reaching 25 percent of GDP in 1989. The tax reform occurred at the beginning of the investment boom while other reforms such as trade liberalization and the privatization of the public pension system significantly predate the boom.

It should be noted that Chile did experience an investment boom from 1976 to 1981 financed by large current account deficits. But this lending boom and following collapse are common to many countries in Latin America over this time period. ${ }^{15}$ As shown in

\footnotetext{
${ }^{14}$ This is consistent with cash constrained firms being owned by liquidity constrained households. If liquidity constraints and cash constraints were not important, a reduction in the retained profits tax rate might merely result in a shift in the composition of savings from household to corporate savings, with no effect on aggregate savings.

${ }^{15}$ The consensus view of these booms are that they were unsustainable lending booms driven by some
} 
Figure $3 b$, only the later investment boom is particular to Chile, since the rest of Latin America stagnated during the $1980^{\prime} s$ following the debt crisis. $^{16}$

What other aggregate evidence can we bring to bear? We first examine the change in the debt to asset ratio for firms during this period. In terms of theory, an unconstrained firm should increase its retention of profits relative to payment of dividends in response to the change in incentives associated with the reduction in the tax on retained earnings. ${ }^{17} \mathrm{~A}$ constrained firm should increase its after-tax retained earnings and increase its investment. In terms of data, the national data cover only publicly traded companies, and publicly traded companies by definition have some access to capital. Thus, the national data on debt ratios reflects the behavior of more unconstrained firms than the national average. As Figure $4 a$ shows, following the reforms, publicly traded firms reduced their debt but only after a significant lag. ${ }^{18}$

Figure $4 b$ shows the impact of the tax reform and investment boom on real tax revenues collected on capital income, both from the personal income tax and the corporate profits tax. ${ }^{19}$ The tax revenues from the category that includes retained profits declines from 250 million 1996 pesos in 1984 to less than 100 million 1996 pesos in 1987. At the same time, the revenues collected from the corporate income tax ( the ten percent tax on all firm profits) rises starting in 1984 as firms invest and grow. From 1989 on, excepting the year 1990 when the retained profits tax was set to zero for a year, the increase in taxes collected through the general profits tax has more than replaced the lost revenues on retained profits. Figure $4 b$ suggests that Chile was able to reduce the tax on retained combination of poorly-regulated financial liberalization and a surge in capital inflows driven by external factors. See, for example, Diaz-Alejandro (1984).

${ }^{16}$ Argentina, Brazil, Columbia, Mexico, and Venezuela are "the rest of Latin America."

${ }^{17}$ There is also a slight reduction in the tax rate on dividends. In a frictionless world, the investment decision of an extant firm that pays dividends is undistorted by dividend taxation (Bradford (1981)).

${ }^{18}$ Note that, as in the United States, despite the favorable tax treatment of retained versus distributed profits, firms maintain fairly high levels of debt. Bustos, Engel, and Galetovic (1998) show that from 1985 to 1995, publicly-traded firms in Chile still carried so much debt such that on average their profits net of interest payments (and depreciation allowances) was effectively zero (or slightly negative).

${ }^{19}$ Figure $3 b$ displays taxes collected during a year rather than the taxes collected on activity during a year. 
earnings and increase tax revenues.

Having presented the basic aggregate facts, we next describe the data on firms and plants that we use to construct industry-level data and to categorize plants by constrained status and test whether constrained plants indeed invested more following the reform.

\section{The Chilean Manufacturing Census}

The data for our analysis of industry and firm investment behavior are drawn from the Chilean Manufacturing Census (Encuesta Nacional Industrial Anual) conducted annually by the Chilean government statistical office (Instituto Nacional de Estadistica). The survey covers all manufacturing plants in Chile with more than ten employees and has been run annually since 1979. In addition to working with the raw data files, we also use some data from an extract from this survey compiled by the World Bank under the direction of James Tybout. Finally, the Chilean statistical agency also provided us with a file containing information on which plants were owned by the same firm. Thus, while we analyze plants, we are able to use the financial situation and behavior of firms to categorize plants as likely or unlikely to be credit constrained.

The advantages of the Chilean Manufacturing Census $(C M C)$ for our purposes are its near universal coverage, annual frequency, and the wealth of information contained about each plant. We combine the information available in the annual surveys from 1979 to 1990 with the World Bank extract which covers only 1979 to 1986. The survey contains information on a wide variety of plant characteristics such as industry (4 digit ISIC), factor inputs, energy use, days of production, sales, and so forth. Of particular interest,

plants report investment, employment and production on an annual basis. The book value of fixed assets is collected in 1980, 1981. The $C M C$ data for year $t$ are collected in surveys conducted in the beginning of year $t+1$. The data contain the value of flow variables over the entire year $t$ and the value of stock variables as of the end of period $t$.

The $C M C$ contains information on five types of investment: purchases of new capital, purchases of used capital, production of capital for own use, improvements in own capital by third parties, and sales of capital. Our measure of investment, to which our capital 
measure corresponds, is the sum of all five types of investment in machinery and equipment and vehicles. That is, we exclude investment in land and buildings. Investment can be negative due to sales of capital and we treat negative reported investment as legitimate. There are a large number of plants that report zero investment from purchases, production, improvements, and sales for all varieties of capital goods. Our primary dataset sets investment to missing only when the World Bank extract considers it missing. This treats the vast majority of zero investment reports as legitimate zeros and treats all such reports after 1986, the last year of the World Bank extract, as legitimate. To check that this assumption is not driving our results, we create an alternative dataset that sets investment (and thus subsequent capital stocks) to missing if there is zero reported investment in all categories and types for two consecutive years. Our baseline results thus use data consistent with those used in previous research, while our alternative dataset checks the robustness of our main results along this dimension. In general our baseline results are robust, and we note any places where our results differ.

Our definition of capital corresponds to our definition of investment, and includes machinery, equipment and vehicles, and excludes buildings. We take our main measures of capital stock from the World Bank extract, which constructs the book value of capital stock in 1980 and 1981 using an inflation adjustment and a depreciation adjustment. To check that our results do not depend on these adjustments, we also construct a separate data extract based on the reported book value of capital as reported in the raw survey data. As with the alternative treatment of investment, our findings are generally robust to this alternative, and we note results for which inference depends on our baseline assumption.

The capital stock for a plant for years besides 1980 and 1981 is calculated by iterating forward using investment and the capital accumulation equation

$$
K_{j, t}=\left(1-\delta_{j}\right) K_{j, t-1}+I_{j, t}
$$

where $j$ indexes either machinery and equipment or vehicles and the timing follows from the fact that investment during year $t$ adds to the capital reported for end of year $t-1$ to capital stock at the end of year $t$. We use the depreciation rates: $10 \%$ for machinery and equipment, and $20 \%$ for vehicles. These are the same rates used in the World Bank extract. In this procedure, we keep capital stocks positive, and omit depreciation for 
plants that are missing from the survey for a year, and drop plants missing for more than one year.

We use the machinery price index to deflate both investment and capital stock. We discard plants that die before the experiment that we seek to study, that is any plant that does not exist after 1983. We drop all plants owned or run by the by government. We consider investment to capital ratios greater than three or less than minus one to be mis-coded or mis-reported and so treat them as missing observations. Finally, there is significant attrition of plants. One quarter of plants attrit between 1984 and 1990 in our baseline sample. Details are contained in appendix $B$, which also provides a further description of the data construction.

\section{Evidence from Chilean industries}

This section presents our main results. We test whether, at the time of the tax reform, investment increases were concentrated in industries for which external finance is important. Rajan and Zingales (1998) construct measures of the reliance of an industry on external finance by examining the use of external finance by US companies. They show that in countries with poorly developed financial markets, industries that are more reliant on external finance grow more slowly relative to the typical growth for that industry and for that country in aggregate. We take a similar tack to identifying the impact of the cut in the tax on retained profits. If capital markets in Chile were poorly developed in the $1980^{\prime} s$ and if the 1984 tax cut disproportionately benefitted plants that are credit constrained, then, in industries that are particularly reliant on external finance, investment rates should rise disproportionately relative to the typical rate for that industry and for Chile in that year.

We thus measure the extent to which industries that are more dependent on external finance have larger increases in investment rates after the reform, relative to their typical investment rates, the average investment rate in that year, and controlling for the fact that if the industry is also capital intensive, it may increase its investment more in response 
to the tax reform. That is, we estimate the following equation

$$
\frac{I_{n, t}}{K_{n, t}}=\alpha_{n}+\gamma_{t}+E_{n} \mathbf{D}_{t} \beta_{E}+F_{n} \mathbf{D}_{t} \beta_{D}+\varepsilon_{i, t}
$$

where $I_{n, t}$ and $K_{n, t}$ are the total investment and capital stock respectively for industry $n$ in year $t, \alpha_{n}$ measures the average investment to capital ratio for industry $n, \gamma_{t}$ measures the average investment to capital ratio in year $t, E_{n}$ is dependence on external finance for industry $n$ as measured by Rajan and Zingales, $\mathbf{D}_{t}$ is a row-vector of indicator variables for years after the tax reform begins, $\beta_{E}$ is the coefficient vector of interest and measures the amount by which $\frac{I_{n, t}}{K_{n, t}}$ is higher for industries that are highly dependent on external finance in each year after the reform, $F_{n}$ is a measure of capital intensity - the average of the 1981 and $1982 \log$ of the ratio of the capital stock in industry $n$ to the to total wages in industry $n$, and the vector $\beta_{D}$ measures the extent to which investment to capital ratios are larger for industries that are more capital intensive in each year after the reform.

Since we estimate this equation on industry-level data from 1982 to 1990, the 'typical' growth rate of an industry is measured by its performance in 1982 and 1983. We also measure typical performance by 1982, 1983, 1989 and 1990, by dropping the last two years of interactions between external dependence and the time indicators and between capital intensity and the time indicators. The first two years have the advantage of being prior to the reform, but the disadvantage that even after controlling for year effects, the pattern of growth across industries may be affected by the severity of the 1982 recession. The last two years have the advantage of being years of healthy growth in Chile, but the disadvantage of being post-reform and after a significant growth boom, when capital markets are beginning to develop more generally.

Table 3 shows the results of estimating equation (2) using weighted least squares where the weights are the number of plants in an industry and making inference allowing for arbitrary cross-industry correlations in each year. ${ }^{20}$ Industries are defined by three-digit

\footnotetext{
${ }^{20}$ Here we use the degree of external dependence as a continuous variable rather than using it to split the sample, as we do subsequently with indicators of possibly constrained status in the plant-level analysis. We choose this functional form to better control for capital intensity. That said, results are substantively similar if we instead split plants into thirds by the Rajan and Zingales measures and also include indicator variables for high, medium or low capital intensity.
} 
ISIC. ${ }^{21}$ The first set of results examines the impact of the reform through 1990, the second set treat 1989 and 1990 as additional "control" years. The coefficients of interest, $\beta_{E, t}$, are negative and insignificant in 1984, positive in 1985 and positive and significant in both sets of results in 1986, and 1987. The last column of the Table quantifies the relative impact of the reform across industries that differ in their degree of financial dependence. An industry one standard deviation above the average level of dependence on external finance is predicted to have increased its capital 13 percent according to the first set of results or 6 percent according to the second by the end of 1987 relative to a comparable industry one standard deviation below the average. Industries that are more dependent on external finance grew more rapidly than usual at the time of the reform. ${ }^{22}$

These results support our thesis that many plants were having difficulty raising external funds in 1983, that plants in industries most dependent on external finance were the most hurt by these constraints, and that in 1985 through 1987, these plants made the largest increases in their investment. We now turn directly to plant-level evidence in which we compare the investment behavior of plants that are likely and unlikely to be cash constrained and control for the typical industry investment levels to see if this dimension of the data also supports our theory.

\section{Evidence from Chilean plants}

This section presents comparisons of the investment behavior of plants that are likely and unlikely to be having trouble raising external funds for productive investment. We measure the likelihood of being constrained based on the correlation of profits and investment before the reform, the amount of short-term capital held by the firm before the reform,

\footnotetext{
${ }^{21}$ The exceptions are food processing and manufacture of fabricated metal, where large numbers of plants allow finer detail, and six industries with few plants that are grouped into three categories. Complete details are in Appendix B.

${ }^{22}$ Results are similar across samples, similar if one omits the control for capital intensity, and similar if one compares the three groups: highly dependent, medium dependence and little dependence on external finance. More capital intensive industries tend to have no consistent pattern of investment rates in 1984 or 1985, statistically insignificant higher investment rates in 1986, and lower investment rates in 1987 and 1988.
} 
whether a firm pays rent, and the size of the firm. When firms are split by investmentprofit correlation, we find a significant effect of the reform as predicted by our theory. There is also some evidence from the sample split by short-term assets. But there is no detectable post-reform investment boom of plants owned by small firms relative to those owned by large firms or of plants owned by firms that pay rent relative to those owned by firms that do not.

Our key dependent variable is investment during year $t$ divided by capital at the start of the year (the end of the previous year):

$$
\left(\frac{I}{K}\right)_{i, t} \equiv \frac{\sum_{j} I_{j, t}}{\sum_{j} K_{j, t-1}}
$$

Table 4 provides a set of statistics on the number of plants, and the mean, standard deviation, and median of investment to capital ratios by year.

To characterize plants as likely or unlikely to have restricted access to capital, we merge plants owned by the same firm together into observations on firms. Each firm, and its associated plants, are categorized into more and less likely to be liquidity constrained on the basis of observed firm characteristics before 1984. Most plants are themselves firms; approximately 350 plants are associated with multi-plant firms during the years of the reform.

We first measure of the likelihood of a plant being credit constrained by the correlation of cash flow and investment for the entire firm during the period before the reforms. ${ }^{23}$ The argument for this measure is standard. Plants that are credit constrained rely more heavily on internal funds to finance operations and so are unable to maintain investment when cash flow drops significantly. Thus, the size of the correlation of cash flow and investment provides a good measure of the degree to which a plant relies on internal funds to finance

\footnotetext{
${ }^{23}$ Our identification strategy is the reverse of that of Calomiris and Hubbard (1995). Calomiris and Hubbard (1995) identify firms as credit constrained or not based on their response to a 1937 surtax imposed on retained earnings. Firms that retain profits despite between 7 and 27 percent additional taxes on such retained profits are called credit constrained. Constrained plants are found to display a higher correlation between investment and cash flow than firms that do not retain profits in the face of this tax. In contrast, we identify credit constraints by sensitivity to cash flow prior to the tax change, and then examine whether constrained plants display a greater response to the tax change.
} 
investment. Our exact measure is the correlation between the ratio of net profits to capital and the ratio of gross investment to capital over the period 1980 to 1982, where we use the 1980 capital stock in place of the unavailable 1979 stock. While we choose this period due to our limited sample, we suspect that this is a good time period for observing which plants are credit constrained since 1982 was a large, temporary downturn. Plants able to maintain some investment or avoid selling off capital in this deep recession are the most likely to have had owners with deep pockets, access to borrowing, or significant internal funds.

We divide our sample of plants into thirds based on our measure of the correlation of profits and investment. We expect the group with the highest correlations to be the most likely to be credit constrained and to benefit the most from the reduction in the tax on retained profits. We call these plants "constrained," the middle third "possibly constrained" and the third of plants with the lowest correlation "unconstrained," however these terms do not imply that we believe this split to be perfect. Given this crude measure there are surely plants that are constrained in the unconstrained sample and vice versa. This should lead any estimates of the impact of the tax reform to be biased towards zero. Following these results we present evidence from several alternative or complementary divisions of plants.

We begin by running the regression:

$$
\ln \left(\frac{I}{K}\right)_{i, t}=\alpha_{i}+\gamma_{t}+C_{i} \mathbf{D}_{t} \boldsymbol{\beta}_{C}+P C_{i} \mathbf{D}_{t} \boldsymbol{\beta}_{P C}+\varepsilon_{i, t}
$$

where $\alpha_{i}$ is a plant-specific fixed effect, $\gamma_{t}$ is a year-specific fixed effect, $C_{i}$ is an indicator of whether a plant is deemed constrained, $P C_{i}$ is an indicator variable for whether a plant is possibly constrained, $\mathbf{D}_{t}$ is a row-vector of indicator variables for years after the tax reform begins, and $\varepsilon_{i, t}$ captures other factors that impact plant's investment choices as well as measurement error in $K$ and $I$. The column-vectors $\boldsymbol{\beta}_{C}$ and $\boldsymbol{\beta}_{P C}$ measure the differential investment activity of plants during and after the tax reform relative to their previous investment rates and relative to the contemporaneous investment choices of plants deemed unlikely to be constrained. We use all available data on plants from 1982 to 1990 and, as before, vary whether 1989 and 1990 are used as control years by varying whether indicator variables for 1989 and 1990 are included in the the vector $\mathbf{D}_{t}$. 
Table 5 presents the estimates from equation (3) in the first and second columns of results. Plants with high correlation of investment and profits through the boom-bust period of 1980 - 1982 show rapid and large increases in investment rates following the tax cuts. Constrained plants on average raise their investment rates by three to four percentage points during the three years of the reform. These estimates control for the average investment rate of a given plant and for the average investment rate in each year. We find similar results if we instead use our alternative series for capital and/or investment. The effect of the reform seems to be persistent. There is little evidence that investment rates slow even several years following the reform, although slightly more evidence for our alternative capital and investment series. Turning to the plants with medium correlations of profits and investment, those that we deem possibly constrained, we also find a significant although smaller investment boom among these plants, again after controlling for both time and plant effects.

Our plant-level results so far rely on the assumption that the differences in the correlation of profits and investment across plants are driven by differences in access to capital rather than differences in technologies and product-specific demands. This assumption might fail if our results are largely comparing plants in different industries. That is, one might be concerned there are some industries that use technologies that happen to produce a high correlation between profits and investment and also happened to boom in the post-1983 period. We first address this alternative by controlling for the investment rate of each plant's industry in each year that we study. We then turn to alternative identification strategies.

We first compare the investment behavior of across differentially-constrained firms relative to the average investment in that industry in that year. That is, we drop the firm and time effects in equation (3), and instead include a set of 33 three-digit industry level dummies interacted with a complete set of time dummy variables. Denoting an industry-time dummy as $\alpha_{j t}$, the estimating equation is given by

$$
\ln \left(\frac{I}{K}\right)_{i, t}=\alpha_{j t}+\gamma_{C} C_{i}+\gamma_{L C} L C_{i}+C_{i} \mathbf{D}_{t} \boldsymbol{\beta}_{C}+L C_{i} \mathbf{D}_{t} \boldsymbol{\beta}_{L C}+\varepsilon_{i, t} .
$$

The coefficients $\gamma_{C}$ and $\gamma_{L C}$ capture the average investment rates of constrained and possibly constrained plants and the coefficient vectors $\boldsymbol{\beta}_{C}$ and $\boldsymbol{\beta}_{L C}$ measure the higher 
investment to capital rates for constrained and possibly constrained plants in each year relative to the average in that industry in that year. The last two columns of results in Table 5 show that our conclusions are robust to this alternative specification. The relative investment rates of constrained and possibly-constrained plants rise significantly during the reform. It is also interesting to note that the coefficients on the indicator variables for constrained and possibly constrained firms are both negative. This indicates that constrained firms invest at lower rates than unconstrained firms, as one might expect.

It is still the case however that we treat a firm as constrained if its correlation is in the top third for all firms rather than relative to the typical correlation in its own industry. Thus we next divide plants by investment-profits correlation relative to the average rate in their industry. A plant is deemed constrained if, among the plants in its four digit industry, it is among the top third in net profits-investment correlation prior to the reform. The results of this exercise are substantively identical to the results in Table 5, and are not reported. Plants we deem likely to be constrained experience larger investment booms. The remainder of the results all classify the constrained status of plants relative to the average values in their industry.

Having established that plants with higher correlations of profits and investment benefit more from the reform, we now investigate alternative assumptions for identifying constrained and unconstrained plants. We consider three other measures of the degree to which a plant is short on internal funds: the ratio of short-term reserves to capital, the ratio of rental payments to capital, and the size of the firm. All of the splits are based on numbers in 1980 and 1981, when book values are reported and well prior to the tax experiment we are considering. On balance, the results of these alternative splits do not clearly support or refute our main hypothesis.

Table 6 shows the relative investment to capital ratios of plants deemed constrained by their holdings of short term reserves in 1980 and 1981. Results are quite similar across the construction of the capital stock series, and robust to whether the 1989 and 1990 years are treated as control years, but differ with respect to the construction of the investment series. Thus Table 6 presents results from the two different constructions of the investment series. The first two sets of results are derived from the baseline series and 
show no significant differential effect of the reform on plants with low short-term asset ratios in 1980 and 1981. The second two sets of results show some increase in investment following the reform, , particularly when we control for the typical growth in each industry in each year, although the evidence is statistically weak.

One possible explanation for the lack of relative investment boom in this split of the data is that firms that are constrained may hold more liquid assets to avoid bankruptcy than plants that can borrow freely. Thus plants with credit lines maintain low levels of short-term assets without bankruptcy risk and contaminate this variable as an indicator of constrained status. There is also the possibility that the high inflation rate leads to a pattern of reserves that is more dependent on monetary factors than real factors. In sum, we conclude that we find some weak support for our hypothesis and no evidence to reject it, when identifying plants as constrained by comparing their level of short term reserves to their industry's average level.

Our second alternative identification strategy is to assume that plants that are financially constrained and have highly productive investment opportunities may be able to rent physical capital to partially loosen the financial constraint. That is, a financially constrained firm is more likely to rent than own the building in which it operates. In Table 7 we investigate whether plants that report paying rental payments benefit more during the years of the reforms. Since most plants report paying no rent, we simply study those that do relative to those that do not. We find no evidence that plants that pay rent invest more following the reform. Our findings are similar whether or not one includes 1989 and 1990 as control years, but differ by capital and investment series, with the results with only one alternative series lying between the reported pairs of results.

The final alternative identification strategy is to assume that small plants are more likely to be constrained. This is standard practice in the literature on credit constrained plants in the United States - small plants are seen as having significantly lower access to credit markets. In Chile, however, four issues arise. First, previous studies have typically measured the size of a plant by its capital stock. Thus, capital stocks in 1980 and 1981 could be used to create a split. However, since only book capital is available and there is significant mismeasurement of initial capital stock, this would create a bias towards 
small plants having high investment to capital ratios early in the sample. This bias would create the incorrect illusion that small plants are growing faster than large plants prior to the tax reform and potentially that their growth slows relative to large plants as the tax reform is instituted. We provide a partial solution to this problem by splitting plants by the average number of employees in 1980 and 1981 rather than by initial capital stock.

The second problem with size as a proxy for financial constraints is that many of the smallest firms in Chile do not pay taxes at all or pay minimal taxes because the owners have low incomes. As Table 2 shows, a firm owned by an individual with a low enough income to have a zero personal tax rate had the same $10 \%$ tax rate on profits before and after the reform. ${ }^{24}$ Third, many small manufacturing plants in Chile are family-run businesses that are perhaps limited in size by economies of scope. The most notable example of this is that 14 percent of our sample is plants in ISIC 3117, bakeries. In the United States, "small" firms in investment studies are usually small public firms, and in 1980 and 1981 in Chile less than one percent of plants are even public. Thus we are really comparing small plants to small plants. Finally, currently, but even more so in the early 1980 's, Chile's financial markets are significantly less developed than those in the United States. Many relatively large plants in Chile do not have access to capital in the same way that relatively large companies in the United States do. In short, size is much less of an indicator of access to capital in Chile and more an indicator of industry, for example. We provide a partial solution to these problems by splitting firms relative to the average size in their industry, as discussed previously.

Table 8 presents the results from dividing plants by size. To re-emphasize how different this exercise is from previous studies of U.S. data, in the typical industry in Chile, small plants are defined as averaging 19 employees or less while large plants are defined as averaging 44 employees or more. As Table 8 shows, there is no evidence that the investment rates of small plants rise (or fall) disproportionately at the time of the tax reform. ${ }^{25}$

\footnotetext{
${ }^{24}$ All of our reported results are similar whether or not we exclude firms that pay no profits tax in the years prior to and including 1982.

${ }^{25}$ Results are similar for the alternative definition of capital and for regressions that include 1989 and 1990 as post-reform years.
} 
In sum, plants that have a high correlation between cash flow (net profits) and investment prior to the reform have the largest increases in investment rates post-reform. This finding is quite robust. However, alternative measures of which firms are likely to be constrained are not supportive of our main thesis.

\section{Could other policy reforms be driving our findings or the investment boom?}

This paper argues that in a country with undeveloped financial markets, investment is constrained by the lack of access to credit. By increasing the internal funds available to profitable firms, the 1984 corporate tax reform in Chile played a large role in unleashing the subsequent rise in Chile's investment and economic growth. However, an alternative hypothesis is that most firms were not credit constrained and that the documented patterns of increases in investment and saving were due to other reforms implemented by Chile's military regime over this time period.

This section describes the major reforms that occurred in Chile in the decade leading up the period of rapid growth: the semi-privatization of the public pension system, the liberalization and development of financial markets, and the opening to trade and capital flows. ${ }^{26}$ Each subsection describes the major policy changes in one area and makes the case that the reforms in question are, based on theory and evidence, unlikely to alter the inferences drawn so far in this paper.

To be clear, we do not mean to argue that these reforms did not benefit Chilean economic growth. Rather we suspect that each of these reforms played a role. Our argument is that these other reforms affected Chile's steady-state levels of output and capital per worker. Convergence to these levels, for most countries and states, is a slow process. But in Chile, the corporate tax reform caused an investment boom and a decade of rapid convergence.

\footnotetext{
${ }^{26}$ See the chapters in Bosworth, Dornbusch, and Laban (1994) and Perry and Leipziger (1999) for a detailed description of the reforms implemented by the Chilean government.
} 


\subsection{Privatization of the public pension system}

Prior to 1981, Chile had an unfunded, pay-as-you-go, public pension system much like the U.S. Social Security system. ${ }^{27}$ The average payroll tax rate varied significantly across firms, but was around 30 percent of wages. ${ }^{28}$ In 1981, the Chilean government cut and standardized the payroll tax, and created a new system which mandated contributions to heavily regulated but privately-managed accounts. All new entrants to the labor force had their payments (20\% of wages), less administrative fees and a share for disability and health insurance (10\% of wages), placed into private accounts which they could invest into one of several regulated mutual funds. ${ }^{29}$ Those employed at the time of the reform had the option to switch into the new system or remain in the old. The new system was immediately popular: 70 percent of private employment switched in the first year. ${ }^{30}$ Elderly workers tended to remain with the old system and 20 percent of the self-employed opted to participate.

The new system was fully funded, with the exception that all plans were guaranteed by the government. To pay the unfunded liabilities of the old system, the government issued a large amount of new debt, "recognition bonds," which were bought by households and slowly paid off by the government. The fiscal costs of payments for these unfunded liabilities averaged 4.7 percent of GDP in $1981-1988 .{ }^{31}$

How might this reform be responsible for the saving and investment boom? First, note that as long as households do not change their consumption behavior and government spending does not change, such a reform has no effect on aggregate national saving. In such a Ricardian world, measured household saving increases by definition because contributions into private accounts are counted as private saving, and this increase is

\footnotetext{
${ }^{27}$ For more complete descriptions, see Edwards (1996) and Diamond (1993).

${ }^{28}$ Exact estimates differ. See Coronado (1997), Gruber (1995), Edwards and Edwards (2000). The rates were significantly higher early in the 1970's.

${ }^{29}$ The health insurance share of the tax could be used by the payee to purchased health insurace from private providers, subject to strict regulation. Among new entrants, the participation of the self-employed was optional, and this has lead to a significant problem of households gaming some of the redistributive nature of the system by moving in and out of self-employment.

${ }^{30}$ Coronado (1997).

${ }^{31}$ Ortuzar (1988), quoted in Edwards (1996), Table 5.
} 
mirrored by the increased public spending necessary to pay the unfunded liabilities of the old system. There is therefore no net effect on aggregate saving.

But Ricardian equivalence seems like a poor assumption to apply to Chile in the early $1980^{\prime} s$. Chile had poorly developed financial markets and, it seems likely that many households and small businesses were financially constrained. However, the impact of this reform is exactly the same as in a Ricardian world if households cannot access or borrow against their private pension accounts. The consumption and investment of constrained households does not change since the privatization merely replaces a government promise with a particular account that the government funds by issuing a government promise. One caveat to this argument is that this reform might alter factor prices, but this does not occur if rates of return are set by the world capital market. That is, the privatization of the pension system does not alter saving and investment if the domestic and/or international capital markets absorb the additional government bonds without altering the domestic real interest rate.

In practice, the privatization seems to have just re-categorized public pension contributions as private instead of public saving. Figure 5 decomposes household saving into contributions to the privatized social security system and into non-social security saving. A significant part of the trend increase in household saving (from -3.8 percent of GDP in $1975-1983$ to 1.7 percent of GDP in $1984-1994)$ is due to contributions into the privatized social security accounts. The increase in measured household saving due to these contributions is mirrored by lower public saving due to the costs of the unfunded liabilities of the old pension system (as shown in Figure $3 a$ ).

Our discussion so far assumes that taxes are nondistortionary. But if private saving incentives were affected by the reform, then the privatization of social security could be partially responsible for the saving boom. For example, if payroll taxes were high and not related to benefits before the reform, then the privatization of social security would increase the incentives to earn by giving households greater benefits for greater taxes paid. An increase in labor supply could lead to an investment boom. Evidence on this point is provided by Gruber (1995), which finds that the incidence of payroll taxes in Chile fell fully on wages, with no effect on employment. According to this evidence, payroll taxes 
under the old system did not create significant labor market distortions.

Another alternative channel is that the privatized pension funds may have led to a deepening of financial markets and so increased both the incentives for households to save and the ease of firm access to financial capital. There is some evidence that non-social security saving increased over the relevant time period (see Figure 5), but the magnitude of the increase - slightly over 3 percent of GDP from 1975 - 1983 to $1984-1994$ - is small relative to the increase in the aggregate saving rate. Financial market development is discussed in the next section. Here we reiterate the well-known theoretical result that even if the reform increased saving, in theory this does not lead to an investment boom in a small open economy like Chile. Many economists are sceptical of this small open economy theoretical argument on empirical grounds: saving rates and investment rates are highly correlated across countries. But if high saving led to high investment in Chile, we would expect to see Chile exporting at least a small amount of capital. In fact, following the reform and through much of the 1980's, Chile ran significant current account deficits, importing capital. This fact is strongly suggestive that high saving did not directly cause high investment, and more importantly that the role of the reform of the public pension system in the investment boom is minimal.

One important final piece of evidence comes from the experiences of the set of countries that reformed their public pension systems. Samwick (2000) studies seven pension reforms in Latin America, seven reforms in Africa, two reforms in Asia, and four reforms in developed economies. Among these countries, there is no evidence that countries that privatized their social security systems experience an increase in saving rates, with one exception: Chile. ${ }^{32}$ It seems unlikely that Chile was the one exception in which the reform of a public pension caused an large increase in saving and investment.

\footnotetext{
${ }^{32}$ Samwick (2000, p.272) concludes, ". . . no country other than Chile that moved to a system of based more on defined contributions during the sample period experienced an increase in the trend saving rates after reform."
} 


\subsection{Liberalization and development of financial markets}

Over the last 25 years, there has been a significant increase in the role of bank credit and publicly-traded equity in Chile's financial markets. ${ }^{33}$ However, most of this deepening of financial markets occurred in the 1970's and in the 1990's. The increase in financial intermediation of the $1990^{\prime} s$ seems a direct result of growth rather than the other way around.

During the first few years of the military regime, Chile focused its efforts on liberalizing the banking sector. From 1974 - 1981, the government lifted interest rate controls, eliminated entry barriers to the banking industry, lowered liquidity requirements for banks, eliminated quantitative controls on credit, and privatized state-owned banks. As shown in Figure $6 a$, the result was a large expansion in bank credit, which increased from 10 percent of GDP in the early 1970 's to almost 60 percent of GDP by the early 1980 's. This development halted with the advent of the debt crisis and the recession of 1982. After the banking crisis of 1982, the government took over most of the country's banks, and, undertook the process of liquidating or recapitalizing and privatizing them, a process which took many years. Bank credit declined significantly in 1982 and continued falling during the beginning of the investment boom. Bank credit reached its low of 40 percent of $G D P$ in 1985-86. A new banking law in 1986 established limits on the leverage positions of the banks, increased reserve requirements, and generally increased the supervisory capacity of the Central Bank over the banking sector. These restrictions kept bank credit roughly constant at 40 percent of GDP until the start of the 1990's. Thus, bank credit was falling as the investment boom began and did not rise as a share of output until investment and saving rates stopped growing.

Turning to the equity market, the stock market played an even more minor role in Chile's financial system in the $1980^{\prime} s$; the market value of publicly traded equity in Chile was 30 percent of $G D P$ in the $1980^{\prime} s$. As shown in Figure $6 b$, it was not until the $1990^{\prime} s$ that the stock market in Chile increased rapidly. The market value of publicly-traded stocks in Chile (relative to GDP) roughly tripled from 35 percent of GDP in 1989 to 94

\footnotetext{
${ }^{33}$ For additional details, see Gallego and Loayza (2000) and Barandarán and Hernández (1999).
} 
percent in $1996 .{ }^{34}$ Since the growth of bank credit was limited in the $1990^{\prime} s$, the deepening of Chile's capital markets during this decade was disproportionately due to the growth in the stock market.

Might these changes in Chile's financial structure have driven the saving and investment boom? They could explain the investment boom if firms that were previously credit constrained were able to obtain financing for their investments as a result of the deepening of Chile's financial markets. However, the aggregate evidence indicates that the investment boom was not financed by external credit but rather by retained earnings. In addition, the timing of the lending boom and the stock market boom in Chile does not support the hypothesis that the investment boom is due to developments in Chile's financial market. The investment boom in Chile took place from 1984 to 1989, but aggregate bank credit did not increase over this time period. Similarly, Chile's equity market did not increase significantly until the $1990^{\prime} s$, after the investment boom. The evidence suggests that the investment boom caused the development of Chile's equity market rather than the reverse. ${ }^{35}$

Finally, we check that our main result is not due to the fact that credit-constrained firms increased borrowing starting in 1984. Recall that we find that the investment of likely constrained firms (measured as firms with a high correlation of investment and cash-flow) increased after 1984 relative to the investment of firms that were likely unconstrained. If this boom was due to an increased access to credit, then we would expect that the ratio of interest payments to capital would rise for our "constrained" firms relative to our "unconstrained" firms. To test this hypothesis, we estimate equations (3) and (4) with interest payments to capital as the dependent variable. We find little evidence of this effect. Table 9 shows the results that match the results presented in Table 5 and there

\footnotetext{
${ }^{34}$ This increase is only partially due to an increase in the price of Chilean equity. In fact, the quantity of Chilean equity, computed by dividing the market value of Chilean stock by its price, increased by 70 percent from 1990 to 1996 (Eyzaguirre and Lefort (1999), Table 3-1 and Figure 3-2).

${ }^{35}$ If the investment boom was driven by the development of Chile's financial markets, then a firm's investment should become less sensitive to cash flow, not more sensitive to cash flow. Gallego and Loayza (2000) find some evidence that the investment of publicly traded companies was less sensitive to cash-flow, but only after the investment boom, that is in the $1990^{\prime} s$ relative to the $1980^{\prime} s$.
} 
is no evidence that the likely-constrained plants borrowed more when their investment boomed. Results using the alternative capital stock series or the alternative investment series also find if anything decreases in interest payments for plants deemed likely to be constrained. However, the alternative capital and investment series together suggest, statistically insignificant but economically significant increases in interest payments for these plants. The balance of the evidence is consistent not with a general increase in available debt instruments and increased access to credit for constrained plants, but rather with increased funds available from internal sources allowing plants with profitable investment opportunities to invest substantially more.

\subsection{Trade liberalization}

Another major reform pursued by Chile in the late 1970 's and early $1980^{\prime} s$ was the liberalization of its trade regime. ${ }^{36}$ During the $1960^{\prime} s$ and early 1970 's, Chile, like many developing economies, pursued policies of import substitution. By 1973, in addition to multiple official exchange rates and quantitative restrictions on imports, the average tariff rate exceeded 100 percent. Among the economic reforms pursued by the Pinochet government was international economic openness, so that by 1979, the average tariff rate had fallen to 12 percent and many of the regulatory restrictions on importing and exporting had been removed. From 1976 to 1981, Chilean manufacturing production grew by 25 percent, but at the same time, the balance of trade worsened and the real exchange rate appreciated significantly.

While the liberalization would seem like a boon to growth and possibly a direct cause of high rates of investment, policy reversed direction during the debt crisis and the deep 1982 recession. By 1984, when the investment boom began, tariffs had been raised to an average of 36 percent, suggesting little role for tariff policy in the investment boom. Indeed, tariffs returned to an average of 15 percent only by 1988. Kasahara (2004) estimates a structural model of investment on the $C M C$ data and argues that the higher tariff rates from 1983 to 1987 actually significantly lowered investment over this period.

To summarize, low tariffs lag economic growth and do not lead it. The investment

\footnotetext{
${ }^{36}$ See Tybout (1996) and Pavcnik (2002).
} 
boom began in 1984, when tariffs rates peaked. Openness may have been an important foundation for growth, but seems unlikely to have been the precipitating factor for the investment boom and growth of the 1980's.

\section{Conclusion}

In 1984, Chile had a poorly developed financial system, with many banks under public control or poorly capitalized. Average tariff rates were double the rates of five years earlier. The semi-privatization of the public pension system had moved a large amount of implicit government debt into an explicit form. Yet, unlike the other Latin American economies, Chile was experiencing the beginning of a large and persistent rise in investment and economic growth.

This paper measures the contribution of a corporate tax reform that lowered the tax on retained profits to this boom. We find that the aggregate and industry level evidence provide clear support for the hypothesis that the reduction in the taxation of retained earnings allowed financially constrained firms to take advantage of profitable investment activities. Specifically, we show that the increase in saving associated with the investment boom was almost entirely an increase in business saving. And more convincingly, controlling for a number of factors, we show that investment rates rose the most in industries that were the most reliant on external finance.

However, the plant level evidence speaks less clearly on our hypothesis. In support of our hypothesis, we find that plants that exhibited a high correlation of investment and cash flow prior to the tax reform increased their investment rates the most during and to some extent following the reform. But other sample splits, included in the paper for completeness, do not reject the null of no effect of the reform. In particular, there is no evidence that smaller plants experienced a larger increase in investment after the tax reform.

Our more general point, supported by the evidence from Chile's tax reform, is that in countries with poorly developed financial markets, taxation of retained profits may have a significant effect on corporate saving and can therefore be particularly harmful for growth. 
By taxing retained profits, the government removes internal funds from some firms where the value of these resources exceed the real interest rate. This argument relies on a country having otherwise favorable macroeconomic policies and conditions. In an economy with high levels of corruption or taxation, poor property rights, poor infrastructure, and so forth, the reduction of a tax on retained profits is likely to accomplish little since investment is low not because of poor financial markets but due to few opportunities for profit. However, in developing economies with strong growth prospects, underdeveloped financial markets may be a significant factor retarding economic growth. Corporate saving is an important source of productive investment, and the Chilean experience shows that policies that increase the internal funds available to firms can have disproportionately large growth effects. 


\section{Appendixes}

\section{A A two period model of credit-constraints, taxes, and investment}

Consider a two-period model of investment in which firms choose capital to maximize profits. Firms face credit constraints and those with low internal funds are constrained from borrowing to invest at the optimal rate. We demonstrate that taxes on retained earnings are particularly harmful in this environment.

We set the tax structure in our simple model to mimic the structure of Chile's taxation of profits, dividends, and retained earnings, as described in detail in the next section. There are three taxes levied on capital income: profits tax $\left(\tau_{p}\right)$, retained profits tax $\left(\tau_{r}\right)$, and dividend income tax $\left(\tau_{d}\right)$. The retained profits and the dividend income tax rate are defined as the tax rate net of the profits tax; the effective tax rate on retained profits is therefore $\tau_{p}+\tau_{r}-\tau_{p} \cdot \tau_{r}$ and that on dividends is $\tau_{p}+\tau_{d}-\tau_{p} \cdot \tau_{d}$.

The economy is small and open so that the interest rate is fixed. We assume that foreign investors require an after tax return of $R^{f}=1+\left(1-\tau_{d}\right) r$ where $r$ is the pre-tax real interest rate in the economy.

The economy is populated by two-period-lived family firms. Firms invest at date 1 and consume at date 2 and maximize the present value of after-tax dividends. There are two types of firms: those who at date 1 have few internal funds, $Y_{1}=Y_{1}^{l c}$ (who will be liquidity constrained); and those who at date 1 have significant internal funds, $Y_{1}=Y_{1}^{n l c}>Y_{1}^{l c}$ (who will not be liquidity constrained). These internal funds are profits from previous activity, and are subject to taxation as such. These resources can be converted into date 2 income either by paying a dividend, or by using these internal funds to buy capital $\left(I^{I}\right)$ in the "family" firm.

$$
\left(1-\tau_{p}\right) Y_{1}=\frac{I^{I}}{1-\tau_{r}}+d_{1}
$$

Internal funds invested are subject to taxation as retained earnings. Both dividends and investment are constrained to be weakly positive.

In addition to investing internal funds, the entrepreneur can borrow to finance investment in the family firm, $I^{B}$, which she repays in the second period at the market interest rate $r$. To capture financial constraints in a simple manner, we assume that the maximum amount the firm 
can borrow is limited to the amount of collateral creditors can seize in the event of a default and that this amount is the entrepreneurs' internal funds. Thus, investment financed by borrowing, $I^{B}$, cannot be greater than after-tax internal funds.

$$
I^{B} \leq\left(1-\tau_{r}\right)\left(1-\tau_{p}\right) Y_{1}
$$

For a firm investing as much as it can, $I^{B}=I^{I}=\left(1-\tau_{r}\right)\left(1-\tau_{p}\right) Y_{1}$.

The family firm produces output net of materials and labor costs in the second period of $Y_{2}=F(K)=F\left(I^{B}+I^{I}\right)$. Firms have access to the same production function regardless of type. Capital depreciates completely.

Finally, we assume that

$$
\begin{aligned}
\left(1-\tau_{r}\right)\left(1+\left(1-\tau_{p}\right)\left(F^{\prime}\left[2\left(1-\tau_{p}\right)\left(1-\tau_{r}\right) Y_{1}^{l c}\right]-1\right)\right) & >1+r \\
F^{\prime}\left[\left(1-\tau_{r}\right)\left(1-\tau_{p}\right) Y_{1}^{n l c}\right] & <1+r
\end{aligned}
$$

which imply: (A1) that the entrepreneur with internal funds $Y_{1}^{l c}$ cannot borrow sufficient to finance the unconstrained optimal amount of investment; and (A2) that the entrepreneur with $Y_{1}^{n l c}$ can borrow the unconstrained optimal amount without hitting the financing constraint.

Firms maximize the present discounted value of after-tax dividends subject to the budget constraint and collateral constraint.

$$
\begin{aligned}
& \operatorname{Max}_{I^{\text {Bor }}, I^{I n t}, d_{1}}\left(1+\left(1-\tau_{d}\right) r\right)\left(1-\tau_{d}\right) d_{1} \\
& +\left(1-\tau_{d}\right)\left[F\left(I^{B}+I^{I}\right)-(1+r) I^{B}-\tau_{p}\left(F\left(I^{B}+I^{I}\right)-I^{I}-I^{B}-r I^{B}\right)\right]
\end{aligned}
$$

subject to $(A .1)$ and $(A .2)$.

The first expression in equation (A.3) is the after-tax value in the second period of dividends paid in the first period. The second term is the after tax value of dividends paid in the second period. The dividends in the second period are after-tax profits, which are output less debt repayment less the profits tax and firms can write off depreciation and interest payments.

For an entrepreneur with sufficient internal funds, the optimal amount of capital is determined by the first order condition for debt $I^{B}$ and the marginal product of capital equals the domestic real interest rate:

$$
F^{\prime}\left[I_{d}^{*}+I_{f}^{*}\right]=1+r
$$


where $I_{d}^{*}$ and $I_{f}^{*}$ are the optimal choices of $I_{d}$ and $I_{f}$. The marginal product of capital of an unconstrained firm is set higher than the world rate of return due to the tax on dividends. Since interest costs are tax deductible, the choice of capital stock is not affected by profit taxes or taxes on retained earnings. ${ }^{37}$ The unconstrained firm pays its first-period profits out as dividends if the wealth of the entrepreneur is higher saving the dividends outside the firm $\left(1-\tau_{d}\right)\left(1+\left(1-\tau_{d}\right) r\right)>\left(1-\tau_{p}\right)\left(1-\tau_{r}\right)(1+r)+\tau_{p}\left(1-\tau_{r}\right)$. This condition is met, for example, when dividends and profits are taxed similarly and retained profits are taxed.

The investment strategy of the entrepreneurs with few internal funds is to borrow and retain earnings so as to invest as much as possible. Equation (A.2) binds, $I_{f}^{*}=I_{d}^{*}=\left(1-\tau_{p}\right)\left(1-\tau_{r}\right) Y_{1}^{l c}$, and the marginal product of capital exceeds the market rate

$$
\left(1-\tau_{r}\right)\left(1+\left(1-\tau_{p}\right)\left(F^{\prime}\left[I_{d}^{*}+I_{f}^{*}\right]-1\right)\right)>1+r .
$$

Since the investment of liquidity constrained firms is constrained to be low, these firms have an after-tax marginal product of capital that exceeds the market interest rate.

There are two important implications of equations (A.4) and (A.5). The distortionary effect of dividend and profits taxes on the capital stock differ for liquidity constrained and nonconstrained firms. The tax on retained profits does not affect the capital stock of firms that do not face binding liquidity constraints. Since they have access to capital markets, these firms are able to make up for a reduced level of internal funds (due to the retained profits tax) by borrowing more from external capital markets. However, dividend taxes distort the choice of capital stock of unconstrained firms, by raising the market real interest rate.

In contrast, a tax on retained profits does reduce the investment and capital stock for constrained firms. Since the capital stock of liquidity constrained firms is limited by their available cash flow, taxes on retained profits, by reducing the amount of internal funds available to the firm, decrease capital stock of these firms one for one. Dividend taxes affect the aftertax second-period income of liquidity-constrained entrepreneurs, but do not affect the capital

\footnotetext{
${ }^{37}$ Because we have specified only the one constraint in capital markets, unconstrained firms are able to choose their capital structure as dictated by tax incentives. Thus , they borrow to finance all new investment. In fact, informational, incentive or bankruptcy constraints seem to cause firms to limit their debt finance and in practice profits taxes are likely to distort capital accumulation. We abstract from these posibilities to keep out model simple and because our focus is not on the corporate profits tax. We do not mean to maintain that distortions from this source are not important.
} 
stock because liquidity-constrained entrepreneurs are already investing their entire first period endowment income in their firms' capital stock.

We note three points about robustness. First, we model the heterogeneity across entrepreneurs as due to differences in internal funds. But the same implications follow if instead entrepreneurs have similar limited levels of internal funds and differ by the productivity of their projects. Then the entrepreneurs who are constrained are those who desire to invest the most - those with the most productive investment opportunities. Second, we have not been explicit about product markets. It is necessary that the size of unconstrained firms be limited by economies of scope (so there is diminishing returns in $F($.$) ) or by demand, such as through$ monopolistic competition. Finally, in a multi-period model, a tax on retained profits reduces optimal investment for an unconstrained firm since the firm can postpone the tax burden of dividends by postponing paying out profits. However, the impact remains significantly less than on the investment behavior of a constrained firm because it affects the marginal return to investment from the optimal level rather than a tightening of a binding constraint.

In sum, for firms that face liquidity constraints, taxes on retained earnings remove cash from inside credit-constrained firms where it is more valuable. In contrast, dividend taxes only distort the investment decisions of firms at their unconstrained optimal capital stocks.

\section{B Additional details on the Chilean manufacturing census}

The $C M C$ survey questionnaires do not directly ask for asset information, but according to the instructions of the survey, plants are supposed to provide a copy of their balance sheets (that they are required to keep for tax purposes). These sheets are the source of the asset information, including the book value of capital, contained in the Survey in 1980 and 1981. Book value is also asked annually since 1992. There is a "book value of assets" measure reported in 1986 and 1987. The 1986 and 1987 numbers are implausibly small (i.e. less than 5 percent of investment) and we do not use them.

We exclude buildings from our measure of capital and investment because the book value of capital in 1980 and 1981 only lists land and buildings together while investment data until 1987 do not include land at all. That is, in 1980 or 1981 we construct capital stock using reports on book value of fixed assets in machinery and equipment, furniture, and vehicles and then distrib- 
ute the amount reported in "other fixed assets" across the three categories (machinery, vehicles and real estate) in the proportion that each category is of the sum of the three. From 1992 on, the reported asset types are: land; buildings; machinery and equipment; and vehicles. The $C M C$ contains information on four main categories of capital investment: buildings; machinery and equipment; vehicles; and, after 1986, land. ${ }^{38}$

In the World Bank extract, the reported book value of capital stock has a monetary adjustment factor (in addition to being deflated to be made real) and is also adjusted to account for some depreciation. Since the documentation is unclear as to how these adjustments are derived, we construct two separate data extracts: one that is based on the reported book value of capital as reported in the raw survey data for 1980 (1981 if 1980 is missing or zero); the other that is based on the "net," "inflation adjusted" capital stock as reported in the World Bank extract for 1980 (1981 if 1980 is missing or zero). "Net" and "inflation adjusted" are the terms used in the Wold Bank documentation.

We use a machinery price index to deflate both investment and fixed assets in machinery and equipment, and vehicles. Capital stock in "other assets" is distributed across categories in the construction of $K$ by category and and the deflation is done after this distribution. We deflate the reported book values of capital stock by the average deflator for year $t$ and year $t+1$ since the reported book values refer to end of year values and the deflators provide a price index for the entire year. Flow variables such as investment are simply deflated by year $t$ price deflators.

In cumulating past capital stocks and investment to construct capital stocks, the data are cleaned in three ways. First, in some rare cases, we infer that the capital stock becomes negative, and we reset these stocks to zero. Since capital is a denominator such an observation is not used in analysis. Since we drop extreme outliers some cases close in time to this observation with unreasonably low capital stocks are also not used. Second, when a plant disappears from the sample for only one year, we assume that it was merely missed in the survey for a year and carry its capital stock forward over the missing year without adjustment. That is we assume that investment roughly equalled depreciation during the omitted year. Finally, plants absent

\footnotetext{
${ }^{38}$ In 1987 and 1988 investment in land is reported under "other" investment; after 1988, land is its own investment category. Prior to 1987, investment in land is not included in the survey; notably it is not included in investment in real estate (whereas in this period land is included in capital stock in real estate).
} 
for more than one year are considered to have become too small to be in the survey or to have gone bankrupt, and any future observations on such a plant are dropped.

A nontrivial number of plants, about 20 percent, switch industry codes at some point during the period over which they are observed. We treat these as legitimate. Firms that are associated with plants that cover multiple industries are associated with the mode industry. Where ties occur they are broken somewhat randomly by choosing the smallest industry code. Most firms operate plants in related industries, and we verified that this allocation rule does not drive any results. Finally, roughly half of plants "attrits" between 1983 and 1990 for the alternative sample that sets investment to missing following two consecutive years of zero reported investment.

Industries are defined by their three-digit ISIC code, except that a) the food production industry (311) is treated as four separate three digit industries since it has so many of the firms in the sample (groups are 3111 and 3112 (meat and dairy); 3113, 3114, and 3115 (canning and oils and fats); 3116, 3118 and 3119 (grains, sugar, and cocoa); 3117 (bakeries); b) 312 (other manufactured foods and animal feed)is grouped with 3140 (tobacco); c) industry 381 (fabricated metal except machines) is also treated more finely - it is simply left at the four digit level; and finally d) due to small numbers, industry 3540 (petroleum and coal) is grouped with 353 (petroleum refineries) and 3620 (glass) is grouped with 361 (pottery and china).

\section{Additional data sources}

Figure 1a: Penn-World Tables.

Figures 1b, 3a, and 5: Bennett, Schmitt-Hebbel, and Soto (1999).

Figure 3b: International Financial Statistics, IMF.

Figure 4a: Central Bank of Chile, "Quarterly Economic and Financial Report of Chile," various issues.

Figure 4b: Ministerio de Hacienda, Direccion de Presupuestos, "Estadisticas de las Finanzas Publicas, 1988-1997," March 1998 and Ministerio de Hacienda, Direccion de Presupuestos, "Ley de Presupuestos del Sector Publico," various years.

Figures 6a and 6b: Eyzaguirre and Lefort (1999), Tables 3-1 and 3-6. 


\section{References}

[1] Agosin, Manuel R. (1999): "What Accounts for the Chilean Saving 'Miracle'," working paper, Universidad de Chile.

[2] Agosin, Manuel R., Crespi T., Gustavo, and Leonardo Letelier S. (1997): "Analysis sobre el aumento del ahorro en Chile," working paper, Interamerican Development Bank.

[3] Barandiaran, Edgardo, and Leonardo Hernandez (1999): “Origin and Resolution of a Banking Crisis: Chile 1982-86," Central Bank of Chile Working Paper No. $5 \%$.

[4] Bennett, Herman, Schmidt-Hebbel, Klaus, and Claudio Soto (1999): "Series de Ahorro e Ingreso por Agente Economico en Chile, 1960-1997," working paper, Banco Central de Chile, no. 53.

[5] Bergoeing, Raphael, Patrick J. Kehoe, Timothy J. Kehoe, And Raimundo Soto (2002): “A Decade Lost and Found: Mexico and Chile in the 1980s," Review of Economic Dynamics, Vol. 5, 166-205.

[6] Bernanke, Ben and Mark Gertler (1995): "Inside the Black Box: The Credit Channel of Monetary Policy Transmission," Journal of Economic Perspectives, Vol. 5 No. 4 (Fall), 27-48.

[7] Bernanke, Ben, Mark Gertler and Simon Gilchrist (1999): "The Financial Accelerator in a Quantitative Business Cycle Framework," in Handbook of Macroeconomics, John Taylor and Michael Woodford, editors. Amsterdam: North-Holland.

[8] Bosworth, Barry, Rudiger Dornbusch, and Raul Laban, editors (1994): The Chilean Economy: Policy Lessons and Challenges, Washington, DC: Brookings Institution.

[9] Bradford, David F. (1981): "The Incidence and Allocation Effects of a Tax on Corporate Distributions," Journal of Public Economics, Vol. 15, 1-22. 
[10] Budnevich, Carlos and Alejandro Jara(1997): "Political Tributaria y Ahorro de las Empresas," Revista de Analysis Economico, Vol. 12 (1), 117-151.

[11] Bustos, Alvaro, Engel, Eduardo, and Alexander Galetovic (1998): "Impuestos y demanda por capital en Chile, 1985-1995," working paper, Universidad de Chile.

[12] Butelmann, Andrea and Francisco Gallego (1999): "Household Savings in Chile," working paper, Central Bank of Chile.

[13] Caballero, Ricardo J. (1999): "Structural Volatility in Chile: A Policy Report," working paper, MIT.

[14] Calomiris, Charles W. and R. Glenn Hubbard (1995): "Internal Finance and Investment: Evidence from the Undistributed Profits Tax of 1936-37," Journal of Business, Vol. 68, No. 4.

[15] Central Bank of Chile : Quarterly Economic and Financial Report of Chile, Santiago, Chile: Banco Central de Chile, various issues.

[16] Coronado, Julia Lynn (1997): "The Effects of Social Security Privatization on Household Saving: Evidence from the Chilean Experience," working paper, Federal Reserve Board of Governors.

[17] Cummins, Jason. G., Kevin A. Hassett and R.Glenn Hubbard (1996), "Tax reforms and investment: a cross-country comparison," Journal of Public Economics, Vol. 62, 237-273.

[18] Diamond, Peter (1993): "Privatization of Social Security: Lessons From Chile," NBER Working Paper No. 4510.

[19] Diaz-Alejandro, Carlos (1983): "Good-Bye Financial Repression, Hello Financial Crash," Journal of Development Economics, Vol. 19 No. 1-2 (Sept.-Oct.), 1-24.

[20] Edwards, Sebastian (1996): "The Chilean Pension Reform: A Pioneering Program," NBER Working Paper No. 5811. 
[21] Edwards, Sebastian and Alejandra Cox Edwards (2000): "Economic Reforms and Labor Markets: Policy Issues and Lessons From Chile," NBER Working Paper No. 7646.

[22] Eyzaguirre, Nicolas and Fernando Lefort (1999): "Capital Markets in Chile, 1985-97: A Case of Successful International Financial Integration," in Chile: Recent Policy Lessons and emerging Challenges, Guillermo Perry and Danny Leipziger, eds., Washington, DC: World Bank, 109-145.

[23] Gallego, Francisco and Norman Loayza (2000): "Financial Structure in Chile: Macroeconomic Developments and Microeconomic Effects," Central Bank of Chile Working Paper No. 75.

[24] Gilchrist, Simon and Charles P. Hummelberg (1995): "Evidence on the role of cash flow for investment," Journal of Monetary Economics, Vol. 36, 541-572.

[25] Gruber, Jonathan (1995): "The Incidence of Payroll Taxation: Evidence From Chile," NBER Working Paper No.5053.

[26] Hasset, Kevin A. and R. Glenn Hubbard (2002): "Tax policy and Business Investment," in: Handbook of Public Economics, A. J. Auerbach \& M. Feldstein (ed.), volume 3, Elsevier, 1293-1343.

[27] Hubbard, R. Glenn (1998): "Capital-Market Imperfections and Investment," Journal of Economic Literature, Vol. XXXVI, 193-225.

[28] Kasahara, Hiroyuki (2004): "Temporary Increases in Tariffs and Machine Replacement: The Chilean Experience," working paper, Queen's University.

[29] Larroulet, Cristian (1987): "Enduedamiento Interno: Origenes, Soluciones, y Perspectives," Estudios Publicos, Vol. 25, 77-103.

[30] Ministerio de Haciendo, Direccion de Presupuestos (1998): Ministerio de Hacienda. 
[31] Ministerio de Haciendo, Direccion de Presupuestos, Ley de Presupuestos del Sector Publico, Santiago, Chile: Ministerio de Hacienda, various years.

[32] Morande, Felipe (1996): "Savings in Chile. What Went Right?" Interamerican Development Bank Working Paper No. 322.

[33] Pavcnik, Nina (2002): "Trade Liberalization, Exit, and Productivity Improvements: Evidence From Chilean Plants," The Review of Economic Studies, Vol. 69 (January), 245-76.

[34] Perry, Guillermo, and Danny Leipziger eds (1999): Chile: Recent Policy Lessons and Emerging Challenges, Washington, DC: World Bank.

[35] Ortuzar, P. (1988): "El Deficit Previsional: Recuento y Proyecciones," in Sistema Privado de Pensiones en Chile, edited by S. Baeza and J. Manubens. Santiago, Centro de Estudios Publicos.

[36] Rajan, Raghuram G. and Luigi Zingales (1998): "Financial Dependence and Growth," American Economic Review, Vol 88 No. 3 (June), 559-86.

[37] Samwick, Andrew A. (2000): "Is Pension Reform Conducive to Higher Saving?" The Review of Economics and Statistics, Vol. 82 No. 2, 264-272.

[38] Servicio de Impuestos Internos (1980): "Estadistica Tributaria: Impuesto a la Renta 1980," Republica de Chile, Servicio de Impuestos Internos.

[39] Tybout, James R. (1996): "Chile 1979-86: Trade Liberalization and Its Aftermath," chapter 9 in Industrial Evolution in Developing Countries, Mark J. Roberts and James R. Tybout eds., Oxford University Press, pp.200-226.

[40] Tybout, James R. (2000): "Manufacturing Firms in Developing Countries: How Well Do They do and Why?" Journal of Economic Literature, Vol. 38, 11-44. 


\begin{tabular}{l|lll||l|c}
\hline \hline Tax Bracket & \multicolumn{3}{|c||}{ Marginal Tax Rates } & Tax Bracket & Marginal Tax Rates \\
$(1983-1985)$ & 1983 & 1984 & 1985 & $(1986)$ & 1986 \\
\hline $0-32,140$ & 0.00 & 0.00 & 0.00 & $0-32,140$ & 0.00 \\
$32,140-80,350$ & 0.08 & 0.07 & 0.06 & $32,140-96,420$ & 0.05 \\
$80,350-128,560$ & 0.13 & 0.12 & 0.11 & $96,420-160,700$ & 0.10 \\
$128,560-176,770$ & 0.18 & 0.17 & 0.16 & $160,700-224,980$ & 0.15 \\
$176,770-224,980$ & 0.28 & 0.27 & 0.26 & $224,980-289,260$ & 0.25 \\
$224,980-273,190$ & 0.38 & 0.37 & 0.36 & $289,260-385,680$ & 0.35 \\
$273,190-321,400$ & 0.48 & 0.47 & 0.46 & $385,680-482,100$ & 0.45 \\
above 321,400 & 0.58 & 0.57 & 0.56 & above 482,100 & 0.50 \\
\hline \hline
\end{tabular}

Table 1: Personal Income Tax Rates in Chile pre and post Reform

Notes. The tax brackets are indexed for inflation. The 1986 tax bracket is quoted in January 1984 pesos p/month 


\begin{tabular}{l|cc|cc}
\hline \hline & \multicolumn{2}{|c|}{ Sociedad Anonimas } & \multicolumn{2}{c}{ Sociedades Limitadas } \\
& Retained Profits & Distributed Profits & Retained Profits & Distributed Profits \\
\hline pre-1984 & 0.460 & $0.244+0.54 \tau$ & $0.10+0.9 \tau$ & $0.10+0.9 \tau$ \\
1984 & 0.370 & $0.118+0.63 \tau$ & 0.10 & $\tau$ \\
1985 & 0.235 & $0.04375+0.765 \tau$ & 0.10 & $\tau$ \\
post 1985 & 0.100 & $\tau$ & 0.10 & $\tau$ \\
\hline \hline
\end{tabular}

Table 2: Tax Rates on Corporate Profits and Dividends in Chile pre and post Reform

Notes. $\tau$ is the marginal personal income tax rate. 


\begin{tabular}{ccc}
\hline & & $\begin{array}{c}\text { Effect of One Standard } \\
\text { Deviation Increase in }\end{array}$ \\
Coefficient & Standard & External Finance \\
& Error & Dependency \\
\hline
\end{tabular}

$\begin{array}{rrrr}\text { Interaction of Dependence on } & & \underline{\text { Panel A }} & \\ \text { External Finance and: } 1984 & -0.024 & (0.015) & -0.010 \\ 1985 & 0.019 & (0.015) & 0.008 \\ 1986 & 0.035 & (0.014) & 0.014 \\ 1987 & 0.046 & (0.015) & 0.019 \\ 1988 & -0.032 & (0.015) & -0.013\end{array}$

Interaction of Dependence on

External Finance and: 1984

1985

$-0.003$

$(0.004)$

$-0.001$

$1986 \quad 0.055$

(0.004)

0.016

$1987 \quad 0.067$

(0.004)

0.022

$1988 \quad-0.011$

(0.004)

0.027

$1989 \quad 0.056$

(0.004)

$-0.004$

$1990 \quad 0.037$

(0.004)

0.023

(0.004)

0.015

Number of Observations: 306

Note: Regressions include industry and year effects captial labor ratio interacted with year effects. Standard errors are calculated allowing for arbitrary heteroskedasticity and cross-industry correlations within each year. Regressions are run on data from 1982 to 1990 and include only plants that survive until at least 1984. Panel A uses 1982, 1983, 1989, and 1990 as control years; Panel B uses only 1982 and 1983. See text for further details. 


\begin{tabular}{|c|c|c|c|c|c|c|c|c|c|}
\hline \multicolumn{5}{|c|}{ Panel A: Baseline Sample } & \multicolumn{5}{|c|}{ Panel B: Alternative Initial Capital Stock } \\
\hline \multicolumn{5}{|c|}{ Capital stock initialized from World Bank extract } & \multicolumn{5}{|c|}{ Capital stock initialized as the reported book value } \\
\hline \multicolumn{5}{|c|}{ Investment missing following the World Bank extract } & \multicolumn{5}{|c|}{ Investment missing following the World Bank extract } \\
\hline Year & $\begin{array}{l}\text { Number of } \\
\text { Observations }\end{array}$ & Mean I/K & $\begin{array}{c}\text { Standard } \\
\text { Deviation } \mathrm{I} / \mathrm{K}\end{array}$ & Median I/K & Year & $\begin{array}{l}\text { Number of } \\
\text { Observations }\end{array}$ & Mean I/K & $\begin{array}{c}\text { Standard } \\
\text { Deviation } \mathrm{I} / \mathrm{K}\end{array}$ & Median I/K \\
\hline 1981 & 3,283 & 0.115 & 0.303 & 0.000 & 1981 & 3,286 & 0.111 & 0.266 & 0.000 \\
\hline 1982 & 3,321 & 0.058 & 0.209 & 0.000 & 1982 & 3,354 & 0.056 & 0.197 & 0.000 \\
\hline 1983 & 3,209 & 0.059 & 0.213 & 0.000 & 1983 & 3,235 & 0.057 & 0.199 & 0.000 \\
\hline 1984 & 3,209 & 0.071 & 0.219 & 0.000 & 1984 & 3,233 & 0.065 & 0.194 & 0.000 \\
\hline 1985 & 3,013 & 0.068 & 0.212 & 0.000 & 1985 & 3,028 & 0.065 & 0.204 & 0.000 \\
\hline 1986 & 2,767 & 0.079 & 0.233 & 0.000 & 1986 & 2,784 & 0.075 & 0.223 & 0.000 \\
\hline 1987 & 2,635 & 0.103 & 0.251 & 0.009 & 1987 & 2,653 & 0.102 & 0.252 & 0.009 \\
\hline 1988 & 2,517 & 0.113 & 0.266 & 0.019 & 1988 & 2,533 & 0.116 & 0.278 & 0.020 \\
\hline 1989 & 2,433 & 0.139 & 0.289 & 0.029 & 1989 & 2,434 & 0.134 & 0.275 & 0.027 \\
\hline 1990 & 2,375 & 0.112 & 0.258 & 0.017 & 1990 & 2,378 & 0.112 & 0.255 & 0.017 \\
\hline \multicolumn{5}{|c|}{$\underline{\text { Panel C: Alternative Investment Series }}$} & \multicolumn{5}{|c|}{ Panel D: Alternative Capital Stock and Investment Series } \\
\hline \multirow{2}{*}{\multicolumn{5}{|c|}{$\begin{array}{l}\text { Capital stock initialized from World Bank extract } \\
\text { Investment missing if zero in two consecutive years }\end{array}$}} & \multirow{2}{*}{\multicolumn{5}{|c|}{$\begin{array}{l}\text { Capital stock initialized as the reported book value } \\
\text { Investment missing if zero in two consecutive years }\end{array}$}} \\
\hline & & & & & & & & & \\
\hline Year & $\begin{array}{l}\text { Number of } \\
\text { Observations }\end{array}$ & Mean I/K & $\begin{array}{c}\text { Standard } \\
\text { Deviation } \mathrm{I} / \mathrm{K}\end{array}$ & Median I/K & Year & $\begin{array}{l}\text { Number of } \\
\text { Observations }\end{array}$ & Mean I/K & $\begin{array}{c}\text { Standard } \\
\text { Deviation } \mathrm{I} / \mathrm{K}\end{array}$ & Median I/K \\
\hline 1981 & 1,907 & 0.2005734 & 0.3781525 & 0.0788183 & 1981 & 1,907 & 0.2041381 & 0.3452066 & 0.0847551 \\
\hline 1982 & 1,757 & 0.1066308 & 0.280374 & 0.0306863 & 1982 & 1,783 & 0.1036753 & 0.2554344 & 0.0305476 \\
\hline 1983 & 1,449 & 0.103754 & 0.2584918 & 0.0302968 & 1983 & 1,464 & 0.0945425 & 0.2267038 & 0.0277332 \\
\hline 1984 & 1,309 & 0.1307663 & 0.2723599 & 0.0499551 & 1984 & 1,321 & 0.1177184 & 0.2378064 & 0.0465582 \\
\hline 1985 & 1,184 & 0.1205192 & 0.2390222 & 0.0457503 & 1985 & 1,186 & 0.1001863 & 0.1807689 & 0.0409718 \\
\hline 1986 & 982 & 0.142286 & 0.2620428 & 0.0643813 & 1986 & 986 & 0.1254738 & 0.2290787 & 0.0575351 \\
\hline 1987 & 831 & 0.1469315 & 0.2320091 & 0.0764872 & 1987 & 834 & 0.1308616 & 0.2008967 & 0.0660726 \\
\hline 1988 & 791 & 0.1503537 & 0.2451368 & 0.0902295 & 1988 & 794 & 0.1383945 & 0.2204166 & 0.0792377 \\
\hline 1989 & 762 & 0.1831413 & 0.2607033 & 0.1085611 & 1989 & 763 & 0.1688204 & 0.2344262 & 0.0992237 \\
\hline 1990 & 727 & 0.1631771 & 0.2540562 & 0.0911481 & 1990 & 730 & 0.1535068 & 0.2518668 & 0.0807679 \\
\hline
\end{tabular}




\begin{tabular}{|c|c|c|c|c|c|c|c|c|}
\hline \multirow{4}{*}{$\begin{array}{l}\text { High correlation indicator: } \\
\text { High corr. plants in: } 1984\end{array}$} & \multicolumn{2}{|c|}{$\underline{\text { Plant and Year Effects }}$} & \multicolumn{2}{|c|}{$\underline{\text { Plant and Year Effects }}$} & \multicolumn{2}{|c|}{$\underline{\text { Industry x Year Effects }}$} & \multicolumn{2}{|c|}{ Industry x Year Effects } \\
\hline & Coefficient & $\begin{array}{c}\text { Standard } \\
\text { Error }\end{array}$ & Coefficient & $\begin{array}{c}\text { Standard } \\
\text { Error }\end{array}$ & Coefficient & $\begin{array}{c}\text { Standard } \\
\text { Error }\end{array}$ & Coefficient & $\begin{array}{c}\text { Standard } \\
\text { Error }\end{array}$ \\
\hline & & & & & -0.021 & $(0.006)$ & -0.039 & $(0.008)$ \\
\hline & 0.049 & $(0.012)$ & 0.063 & $(0.013)$ & 0.044 & $(0.013)$ & 0.063 & $(0.014)$ \\
\hline 1985 & 0.032 & $(0.012)$ & 0.046 & $(0.013)$ & 0.031 & $(0.013)$ & 0.049 & $(0.014)$ \\
\hline 1986 & 0.024 & $(0.013)$ & 0.038 & $(0.014)$ & 0.024 & $(0.013)$ & 0.042 & $(0.014)$ \\
\hline 1987 & 0.008 & $(0.013)$ & 0.023 & $(0.014)$ & 0.008 & $(0.014)$ & 0.026 & $(0.015)$ \\
\hline 1988 & 0.031 & $(0.013)$ & 0.046 & $(0.014)$ & 0.033 & $(0.014)$ & 0.051 & $(0.015)$ \\
\hline 1989 & & & 0.039 & $(0.014)$ & & & 0.045 & $(0.015)$ \\
\hline 1990 & & & 0.024 & $(0.014)$ & & & 0.036 & $(0.015)$ \\
\hline edium correlation indicator: & & & & & -0.039 & $(0.006)$ & -0.058 & $(0.008)$ \\
\hline Medium corr. plants in: 1984 & 0.024 & $(0.012)$ & 0.041 & $(0.013)$ & 0.023 & $(0.012)$ & 0.042 & $(0.013)$ \\
\hline 1985 & 0.016 & $(0.012)$ & 0.034 & $(0.013)$ & 0.017 & $(0.013)$ & 0.036 & $(0.013)$ \\
\hline 1986 & 0.011 & $(0.012)$ & 0.029 & $(0.013)$ & 0.013 & $(0.013)$ & 0.033 & $(0.014)$ \\
\hline 1987 & 0.023 & $(0.013)$ & 0.042 & $(0.014)$ & 0.023 & $(0.013)$ & 0.042 & $(0.014)$ \\
\hline 1988 & 0.031 & $(0.013)$ & 0.051 & $(0.014)$ & 0.034 & $(0.013)$ & 0.053 & $(0.014)$ \\
\hline 1989 & & & 0.038 & $(0.014)$ & & & 0.038 & $(0.014)$ \\
\hline 1990 & & & 0.046 & $(0.014)$ & & & 0.051 & $(0.015)$ \\
\hline Number of Observations: & 24,5 & & 24 & & 24 & & 24 , & \\
\hline
\end{tabular}

\footnotetext{
Note: Correlation categorizations are based on the three observations of investment to capital ratios and net profit to capital ratios in 1980, 1981, and 1982. Regressions are run on data from 1982 to 1990 and include only plants that survive until at least 1984. See text for further details.
} 


\begin{tabular}{|c|c|c|c|c|c|c|c|c|}
\hline & \multicolumn{4}{|c|}{$\underline{\text { Baseline Series }}$} & \multicolumn{4}{|c|}{$\underline{\text { Alternative Investment Series }}$} \\
\hline & \multicolumn{2}{|c|}{$\underline{\text { Plant and Year Effects }}$} & \multicolumn{2}{|c|}{$\underline{\text { Industry x Year Effects }}$} & \multicolumn{2}{|c|}{$\underline{\text { Plant and Year Effects }}$} & \multicolumn{2}{|c|}{$\underline{\text { Industry x Year Effects }}$} \\
\hline & Coefficient & $\begin{array}{c}\text { Standard } \\
\text { Error }\end{array}$ & Coefficient & $\begin{array}{c}\text { Standard } \\
\text { Error }\end{array}$ & Coefficient & $\begin{array}{c}\text { Standard } \\
\text { Error }\end{array}$ & Coefficient & $\begin{array}{c}\text { Standard } \\
\text { Error }\end{array}$ \\
\hline Low assets indicator: & & & -0.019 & $(0.006)$ & & & -0.016 & $(0.010)$ \\
\hline Low plants in: 1984 & -0.005 & $(0.011)$ & -0.002 & $(0.012)$ & -0.001 & $(0.020)$ & 0.031 & $(0.022)$ \\
\hline 1985 & 0.012 & $(0.011)$ & 0.013 & $(0.012)$ & 0.020 & $(0.021)$ & 0.035 & $(0.023)$ \\
\hline 1986 & 0.008 & $(0.012)$ & 0.010 & $(0.013)$ & 0.020 & $(0.023)$ & 0.035 & $(0.025)$ \\
\hline 1987 & -0.001 & $(0.012)$ & 0.010 & $(0.013)$ & 0.003 & $(0.025)$ & 0.010 & $(0.027)$ \\
\hline 1988 & 0.007 & $(0.012)$ & 0.017 & $(0.013)$ & 0.005 & $(0.026)$ & 0.011 & $(0.028)$ \\
\hline Medium assets indicator: & & & -0.041 & $(0.006)$ & & & -0.049 & $(0.009)$ \\
\hline Medium plants in: 1984 & -0.006 & $(0.011)$ & -0.004 & $(0.012)$ & -0.016 & $(0.019)$ & -0.003 & $(0.020)$ \\
\hline 1985 & 0.013 & $(0.012)$ & 0.016 & $(0.012)$ & 0.006 & $(0.020)$ & 0.019 & $(0.021)$ \\
\hline 1986 & 0.007 & $(0.012)$ & 0.006 & $(0.013)$ & 0.003 & $(0.021)$ & -0.002 & $(0.022)$ \\
\hline 1987 & 0.021 & $(0.012)$ & 0.022 & $(0.013)$ & 0.027 & $(0.022)$ & 0.020 & $(0.024)$ \\
\hline 1988 & 0.003 & $(0.012)$ & 0.003 & $(0.013)$ & -0.008 & $(0.023)$ & -0.022 & $(0.025)$ \\
\hline Number of Observations: & \multicolumn{2}{|c|}{24,666} & \multicolumn{2}{|c|}{24,666} & \multicolumn{2}{|c|}{9,404} & \multicolumn{2}{|c|}{9,404} \\
\hline
\end{tabular}

Note: All regressions include year and plant indicator variables. Categorizations are based on the ratio of short-term assets to capital in 1980 and 1981 relative to the industry average. Regressions are run on data from 1982 to 1990 and include only plants that survive until at least 1984. See text for further details. 
Table 7: Investment to Capital as a Function of Whether a Firm Pays Rent

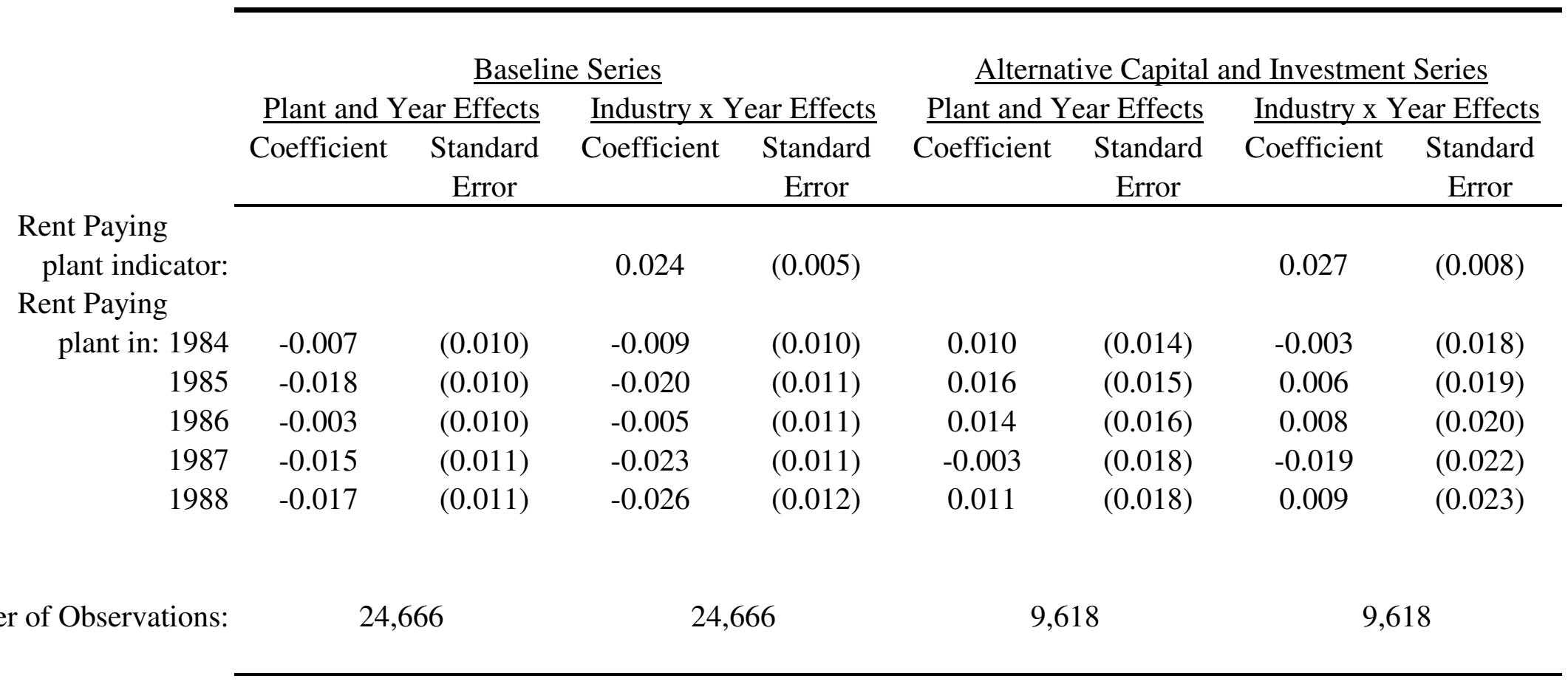

Note: Plants are categorized as rent-payers based on 1980 and 1981 data. Regressions are run on data from 1982 to 1990 and include only plants that survive until at least 1984. See text for further details. 


\begin{tabular}{|c|c|c|c|c|c|c|c|c|}
\hline & \multicolumn{4}{|c|}{$\underline{\text { Baseline Series }}$} & \multicolumn{4}{|c|}{$\underline{\text { Alternative Investment Series }}$} \\
\hline & \multicolumn{2}{|c|}{$\underline{\text { Plant and Year Effects }}$} & \multicolumn{2}{|c|}{ Industry x Year Effects } & \multicolumn{2}{|c|}{$\underline{\text { Plant and Year Effects }}$} & \multicolumn{2}{|c|}{ Industry x Year Effects } \\
\hline & Coefficient & $\begin{array}{c}\text { Standard } \\
\text { Error }\end{array}$ & Coefficient & $\begin{array}{c}\text { Standard } \\
\text { Error } \\
\end{array}$ & Coefficient & $\begin{array}{c}\text { Standard } \\
\text { Error }\end{array}$ & Coefficient & $\begin{array}{c}\text { Standard } \\
\text { Error }\end{array}$ \\
\hline Small plant indicator: & & & -0.021 & $(0.006)$ & & & 0.026 & $(0.010)$ \\
\hline Small Plants in: 1984 & 0.008 & $(0.011)$ & -0.005 & $(0.013)$ & 0.038 & $(0.020)$ & 0.019 & $(0.021)$ \\
\hline 1985 & -0.004 & $(0.011)$ & -0.019 & $(0.013)$ & 0.016 & $(0.020)$ & 0.008 & $(0.022)$ \\
\hline 1986 & -0.004 & $(0.012)$ & -0.015 & $(0.013)$ & -0.042 & $(0.022)$ & -0.031 & $(0.024)$ \\
\hline 1987 & 0.038 & $(0.012)$ & 0.031 & $(0.014)$ & -0.019 & $(0.024)$ & -0.003 & $(0.026)$ \\
\hline 1988 & 0.020 & $(0.012)$ & 0.008 & $(0.014)$ & -0.006 & $(0.024)$ & 0.024 & $(0.026)$ \\
\hline Medium plant indicator: & & & -0.009 & $(0.005)$ & & & -0.007 & $(0.009)$ \\
\hline Medium Plants in: 1984 & 0.008 & $(0.011)$ & 0.005 & $(0.012)$ & 0.024 & $(0.019)$ & 0.024 & $(0.020)$ \\
\hline 1985 & 0.006 & $(0.011)$ & 0.006 & $(0.012)$ & -0.001 & $(0.020)$ & 0.008 & $(0.020)$ \\
\hline 1986 & -0.002 & $(0.012)$ & -0.003 & $(0.012)$ & 0.032 & $(0.021)$ & 0.031 & $(0.022)$ \\
\hline 1987 & 0.008 & $(0.012)$ & 0.004 & $(0.012)$ & 0.016 & $(0.023)$ & 0.014 & $(0.024)$ \\
\hline 1988 & 0.023 & $(0.012)$ & 0.022 & $(0.013)$ & 0.033 & $(0.023)$ & 0.042 & $(0.024)$ \\
\hline Number of Observations: & 25,4 & & 25,4 & & 9,7 & & 9,7 & \\
\hline
\end{tabular}

Note: Size categorizations are based on the percent difference in firm employment in 1980 and 1981 from the industry average. Regressions are run on data from 1982 to 1990 and include only plants that survive until at least 1984. See text for further details. Results using the alternative capital series and including 1989 and 1990 interactions yeild similar results. 


\begin{tabular}{|c|c|c|c|c|c|c|c|c|}
\hline \multirow{4}{*}{$\begin{array}{l}\text { High correlation indicator: } \\
\text { High corr. plants in: } 1984\end{array}$} & \multicolumn{2}{|c|}{ Plant and Year Effects } & \multicolumn{2}{|c|}{ Plant and Year Effects } & \multicolumn{2}{|c|}{$\underline{\text { Industry x Year Effects }}$} & \multicolumn{2}{|c|}{ Industry x Year Effects } \\
\hline & Coefficient & $\begin{array}{l}\text { Standard } \\
\text { Error }\end{array}$ & Coefficient & $\begin{array}{l}\text { Standard } \\
\text { Error }\end{array}$ & Coefficient & $\begin{array}{l}\text { Standard } \\
\text { Error }\end{array}$ & Coefficient & $\begin{array}{l}\text { Standard } \\
\text { Error }\end{array}$ \\
\hline & & & & & 0.131 & $(0.051)$ & 0.196 & $(0.068)$ \\
\hline & -0.052 & $(0.086)$ & -0.138 & $(0.093)$ & -0.024 & $(0.109)$ & -0.090 & $(0.118)$ \\
\hline 1985 & -0.090 & $(0.088)$ & -0.180 & $(0.095)$ & -0.141 & $(0.111)$ & -0.206 & $(0.120)$ \\
\hline 1986 & -0.140 & $(0.090)$ & -0.232 & $(0.097)$ & -0.183 & $(0.114)$ & -0.249 & $(0.123)$ \\
\hline 1987 & -0.194 & $(0.092)$ & -0.288 & $(0.099)$ & -0.125 & $(0.116)$ & -0.190 & $(0.125)$ \\
\hline 1988 & 0.002 & $(0.093)$ & -0.094 & $(0.101)$ & 0.035 & $(0.118)$ & -0.031 & $(0.126)$ \\
\hline 1989 & & & -0.206 & $(0.102)$ & & & -0.141 & $(0.128)$ \\
\hline 1990 & & & -0.222 & $(0.103)$ & & & -0.166 & $(0.129)$ \\
\hline edium correlation indicator: & & & & & -0.030 & $(0.050)$ & -0.072 & $(0.066)$ \\
\hline Iedium corr. plants in: 1984 & -0.003 & $(0.083)$ & 0.035 & $(0.089)$ & 0.009 & $(0.106)$ & 0.051 & $(0.115)$ \\
\hline 1985 & 0.030 & $(0.085)$ & 0.070 & $(0.091)$ & 0.006 & $(0.109)$ & 0.048 & $(0.117)$ \\
\hline 1986 & -0.020 & $(0.088)$ & 0.022 & $(0.094)$ & -0.028 & $(0.112)$ & 0.014 & $(0.120)$ \\
\hline 1987 & -0.007 & $(0.089)$ & 0.036 & $(0.096)$ & 0.006 & $(0.115)$ & 0.048 & $(0.123)$ \\
\hline 1988 & 0.048 & $(0.091)$ & 0.092 & $(0.098)$ & 0.054 & $(0.117)$ & 0.096 & $(0.125)$ \\
\hline 1989 & & & 0.096 & $(0.099)$ & & & 0.098 & $(0.126)$ \\
\hline 1990 & & & 0.116 & $(0.100)$ & & & 0.111 & $(0.127)$ \\
\hline Number of Observations: & \multicolumn{2}{|c|}{24,631} & \multicolumn{2}{|c|}{24,631} & \multicolumn{2}{|c|}{24,631} & \multicolumn{2}{|c|}{24,631} \\
\hline
\end{tabular}

\footnotetext{
Note: Correlation categorizations are based on the three observations of investment to capital ratios and net profit to capital ratios in 1980, 1981, and 1982. Regressions are run on data from 1982 to 1990 and include only plants that survive until at least 1984. See text for further details.
} 
Figure 1a

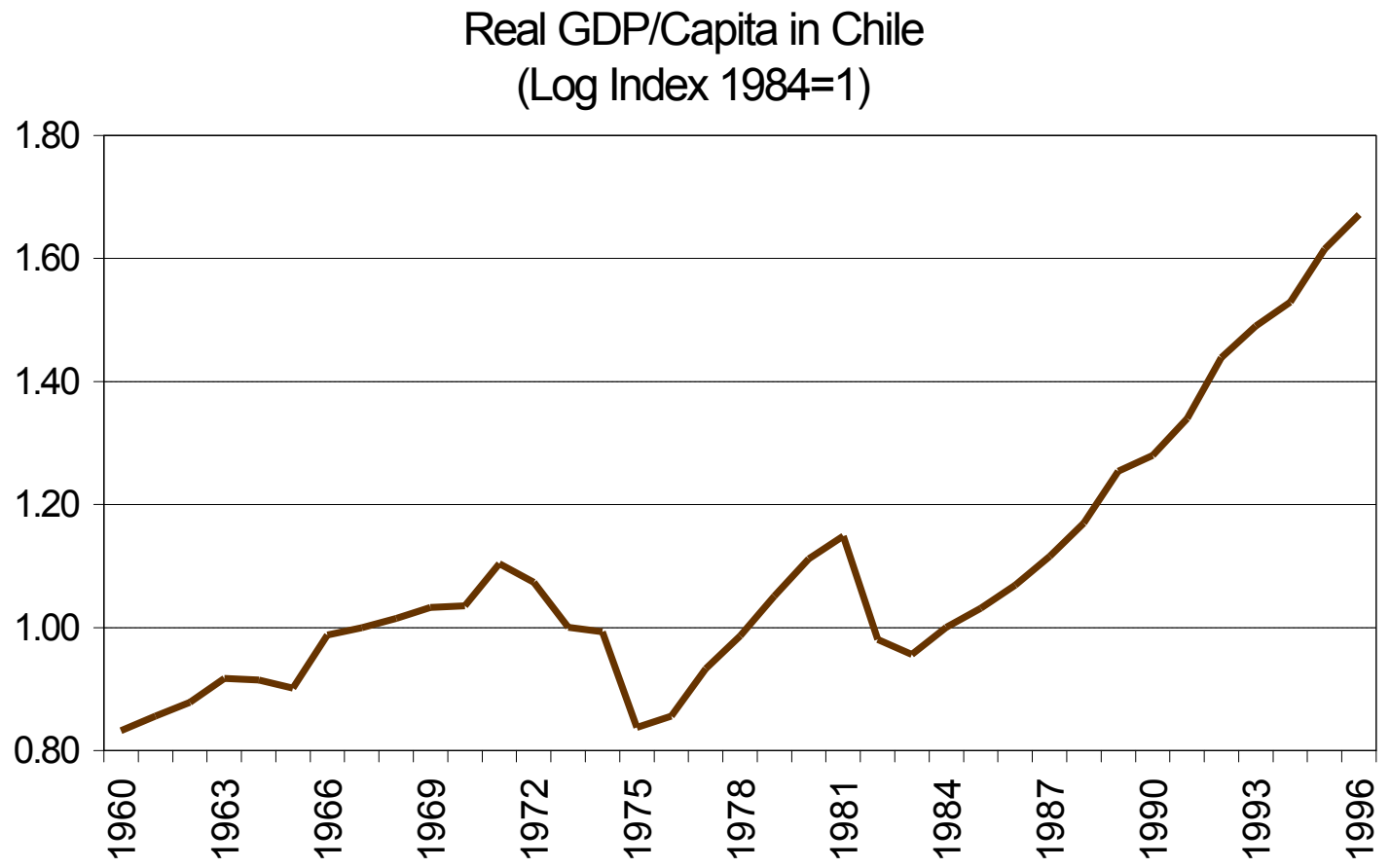

Figure 1b

Saving and Investment Rates in Chile

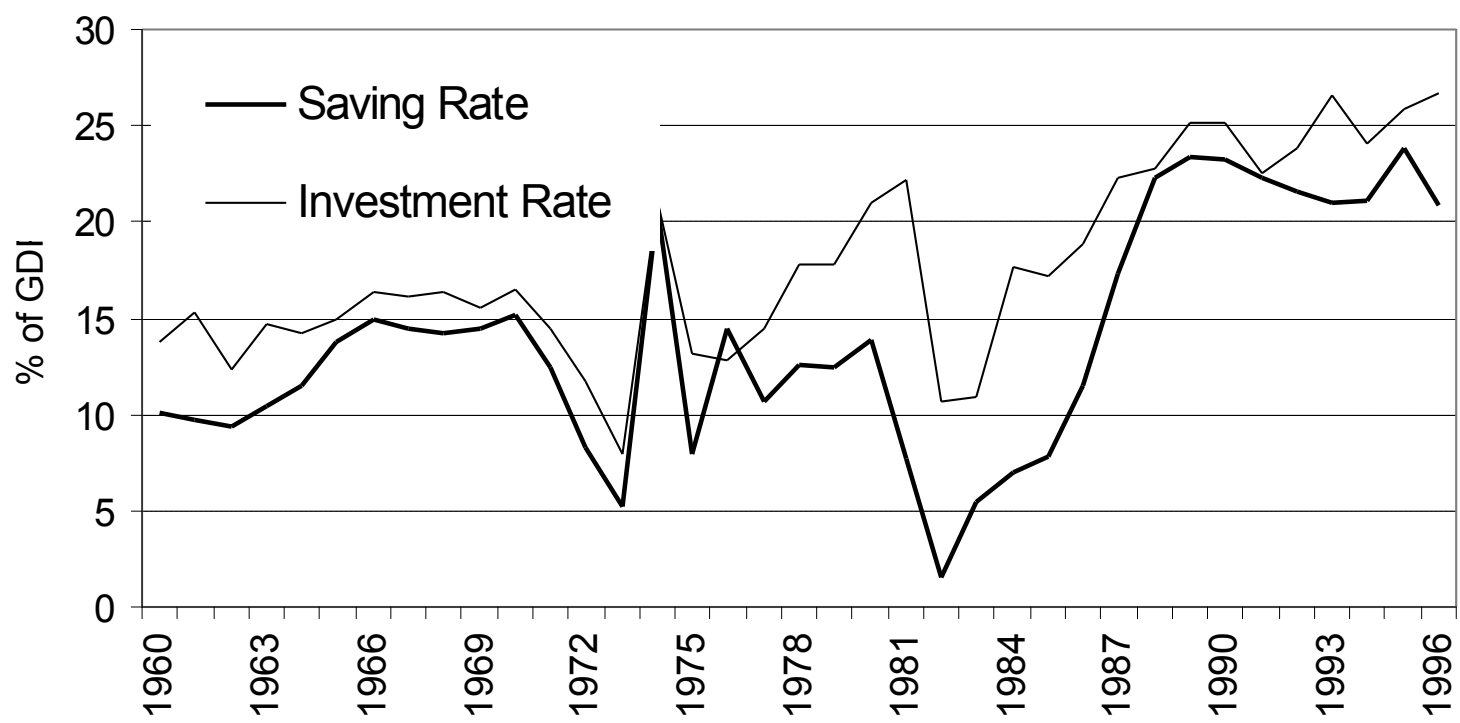




\section{Figure 2: Investmentand Credit Constraints}

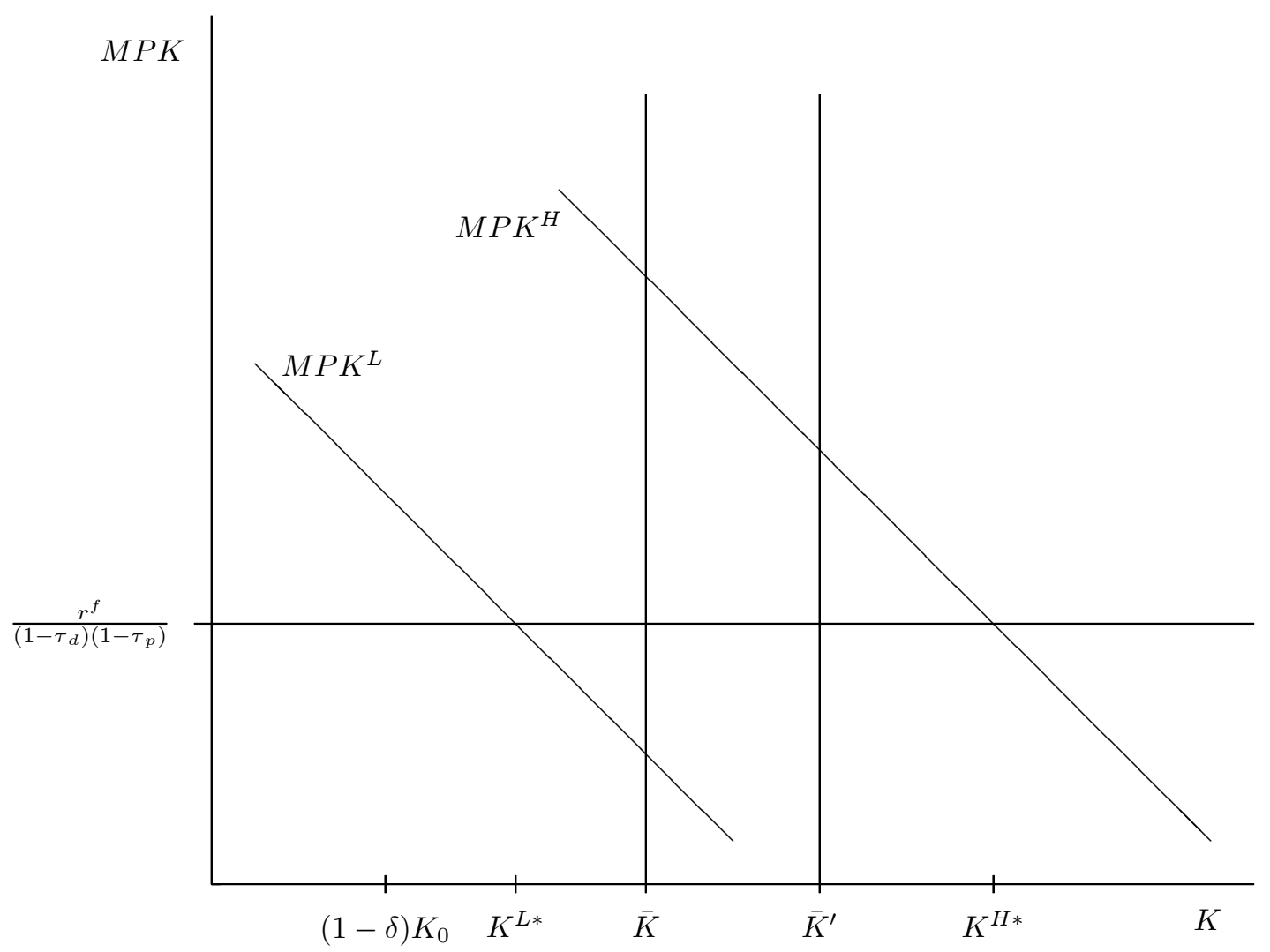


Figure $3 \mathrm{a}$

Sources of Saving in Chile

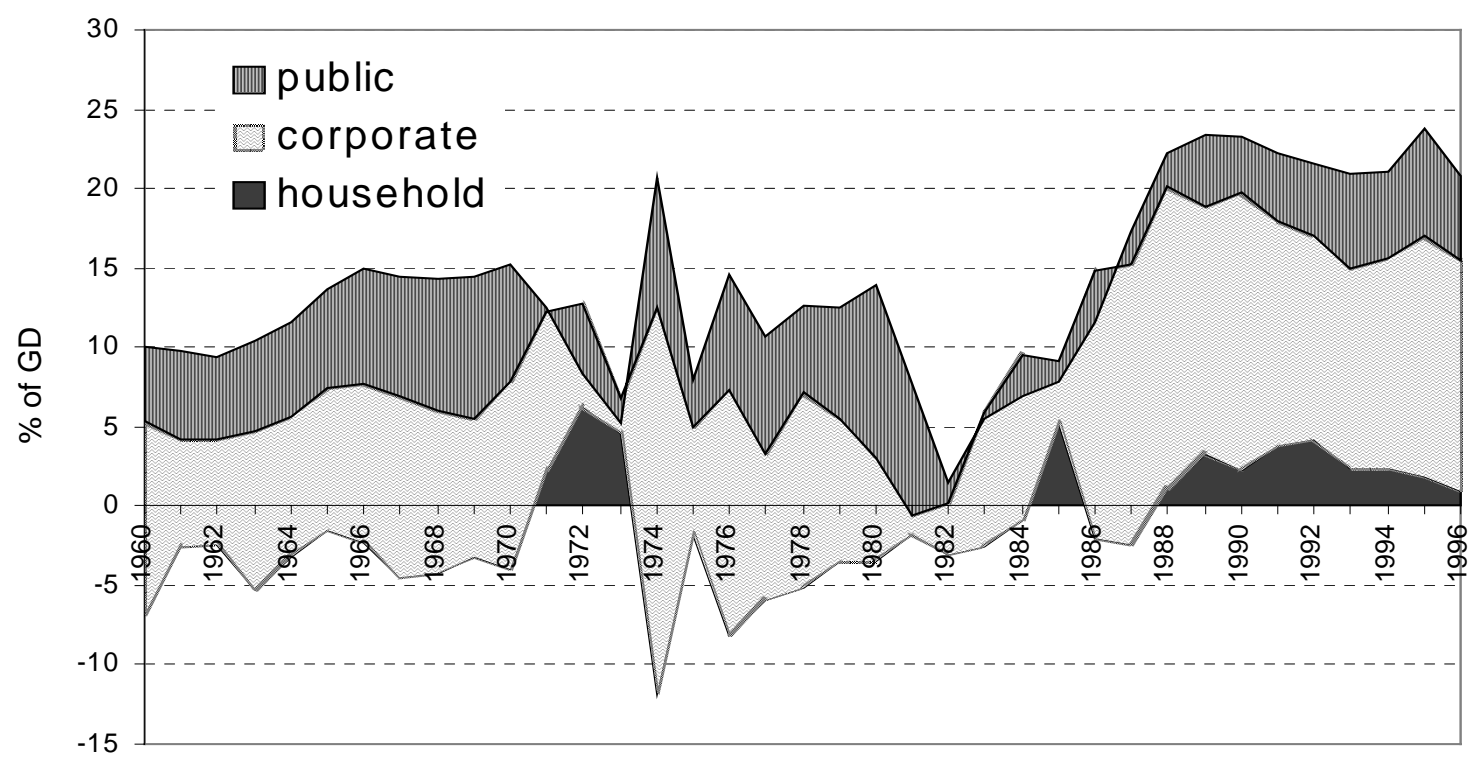

Figure $3 b$

Investment to GDP in Latin America

Argentina, Brazil, Colombia, Mexico, and Venezuela

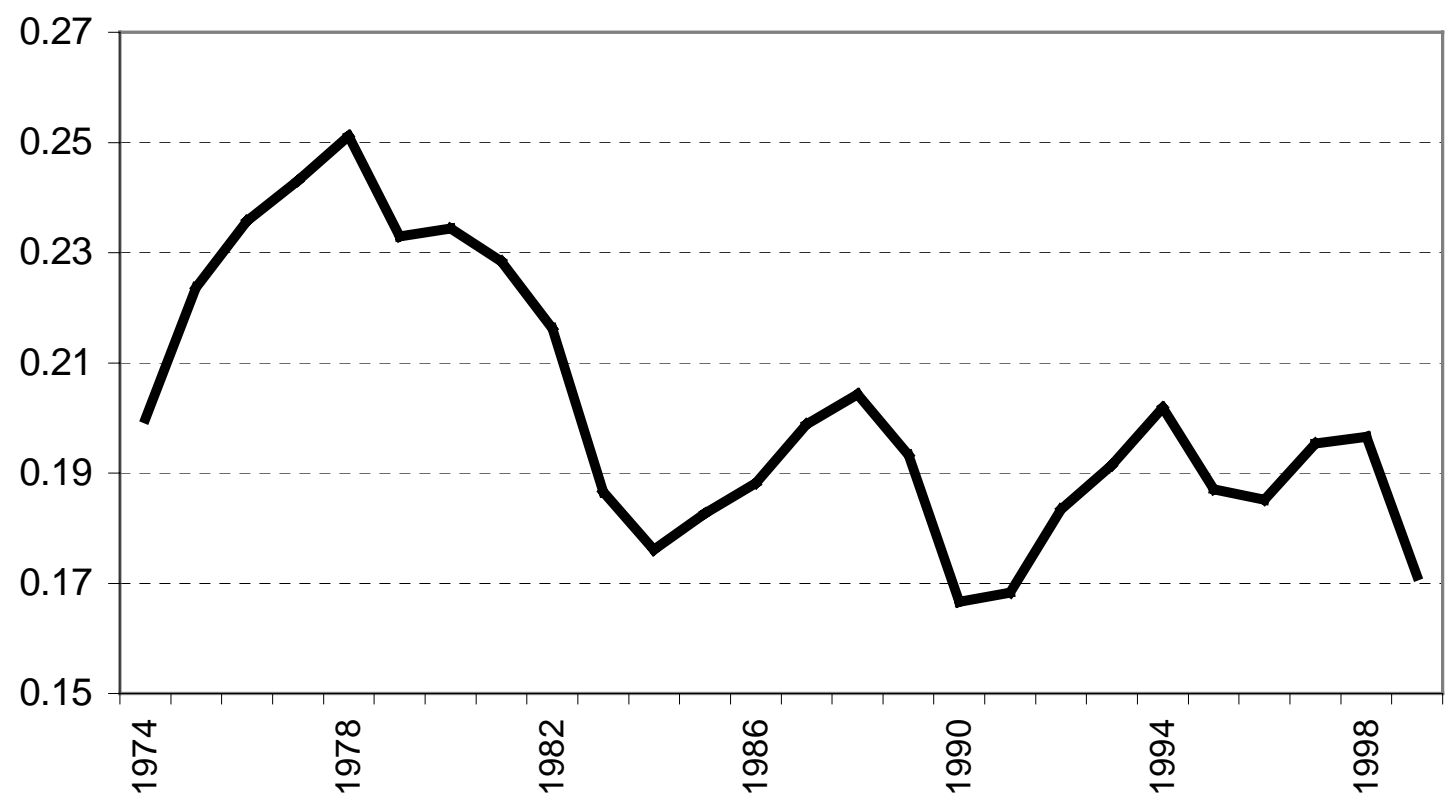


Figure 4a

Debt/Total Assets of Publicly Traded Companies

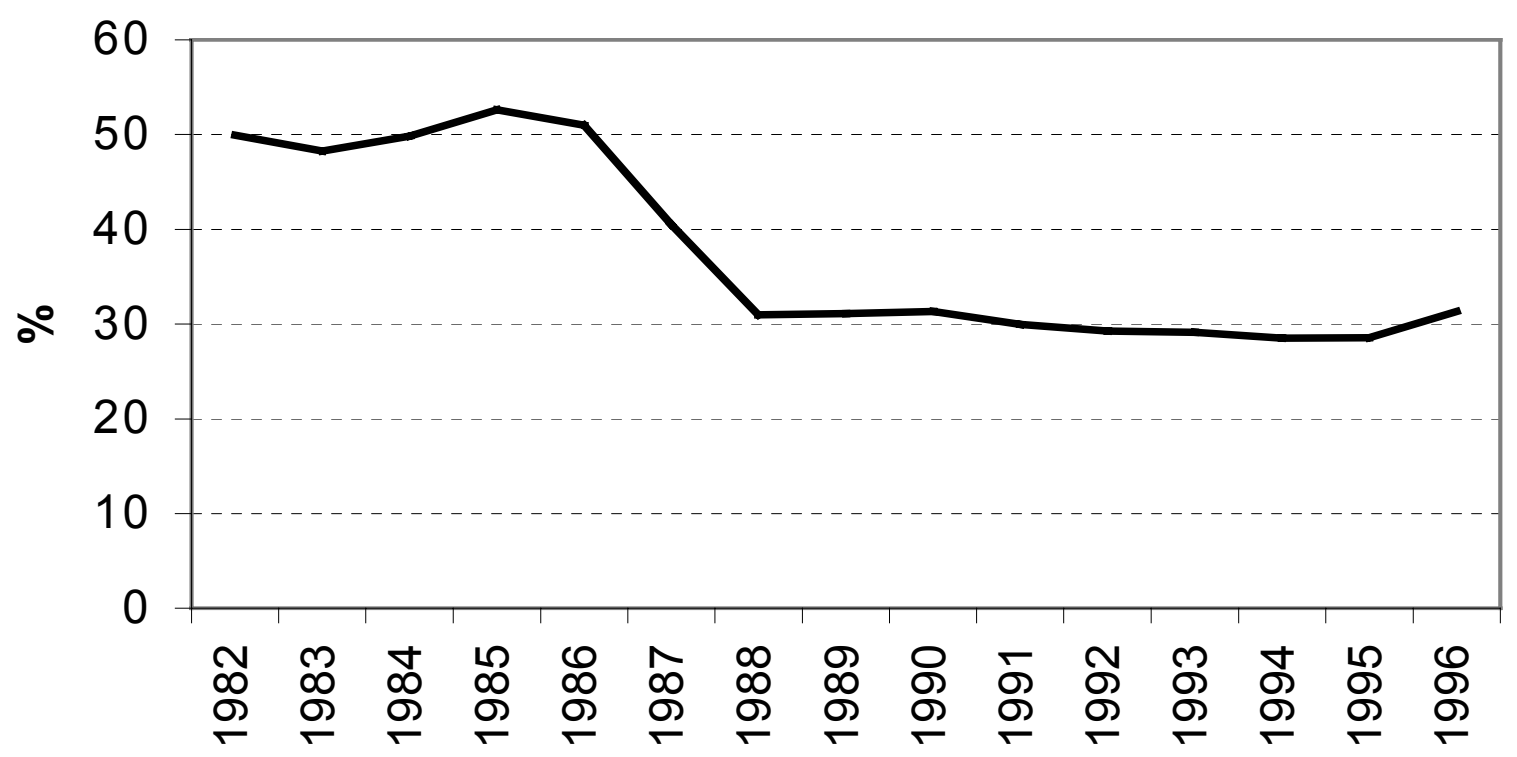

Figure $4 b$

\section{Tax Revenues from Capital Income}

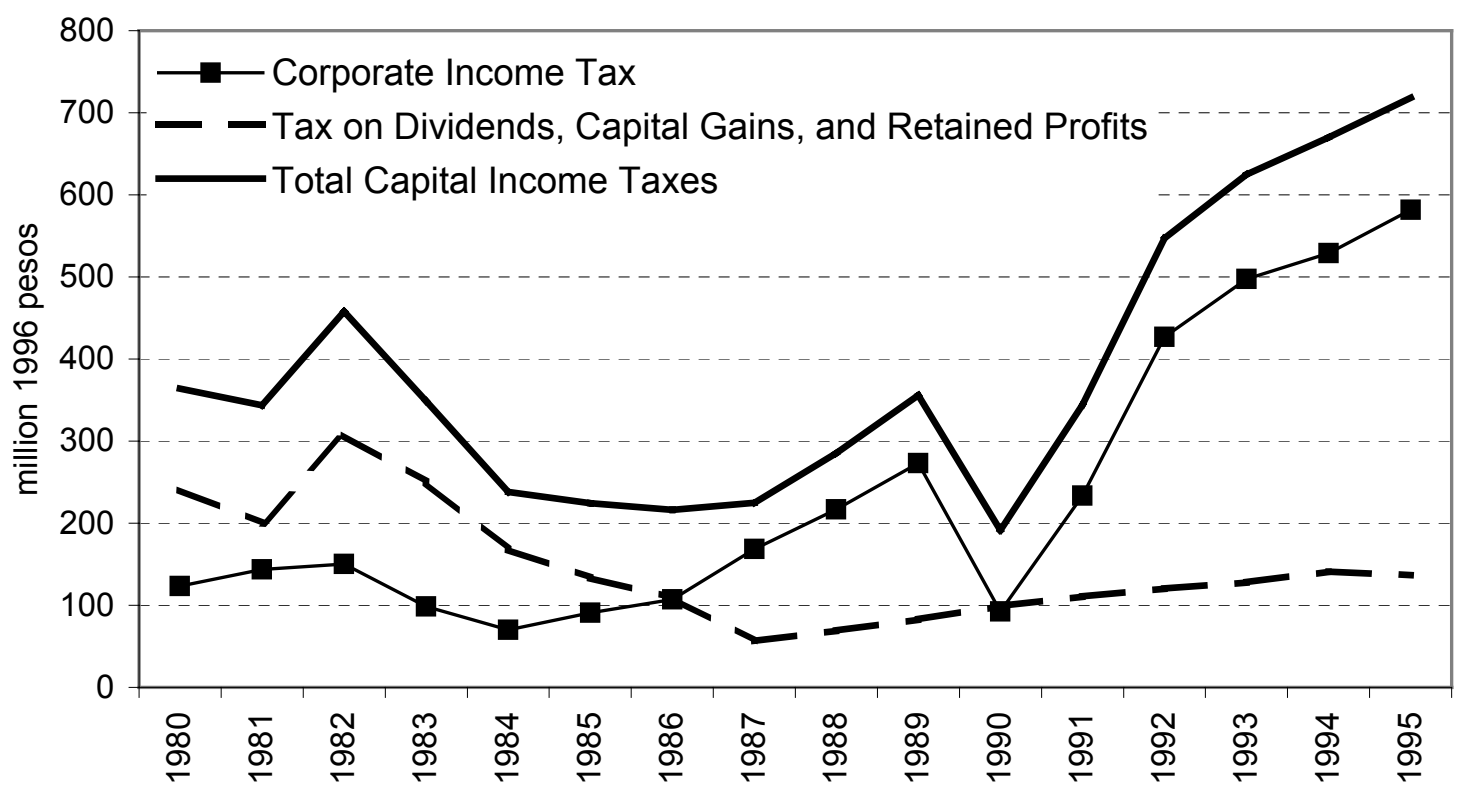


Figure 5

\section{Household Savings}

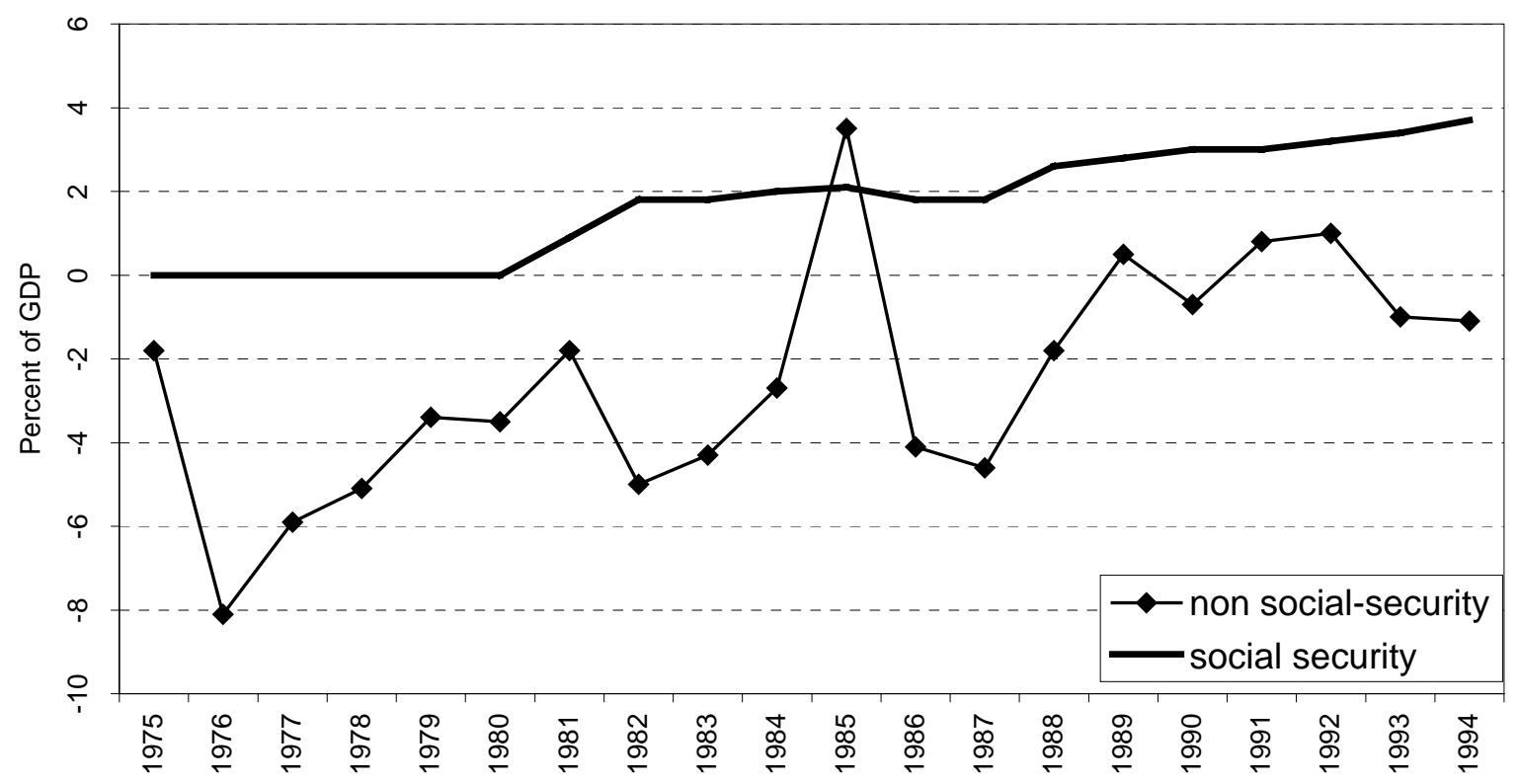


Figure 6a

\section{Bank Credit}

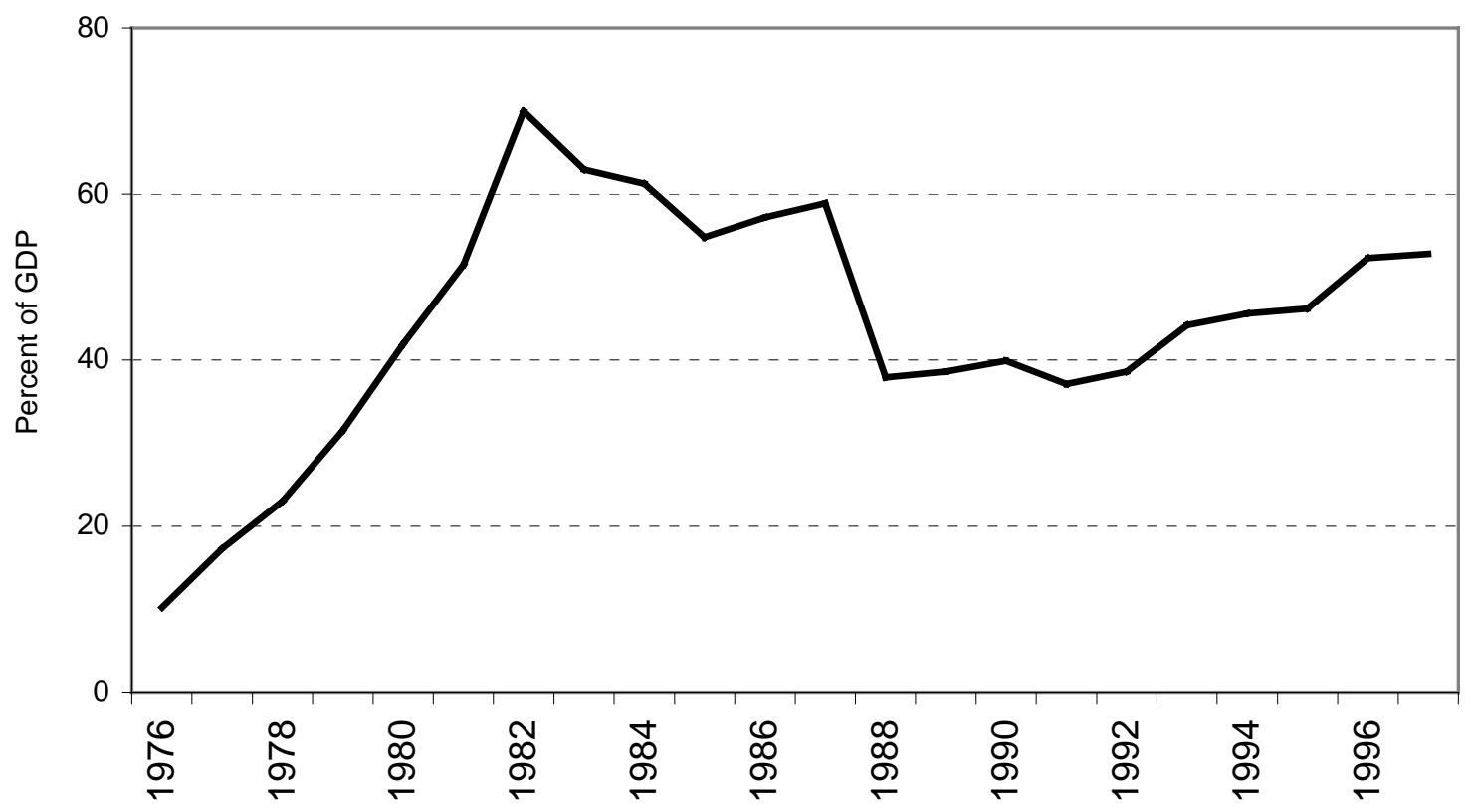

Figure $6 b$

\section{Market Value of Publicly Traded Stocks}

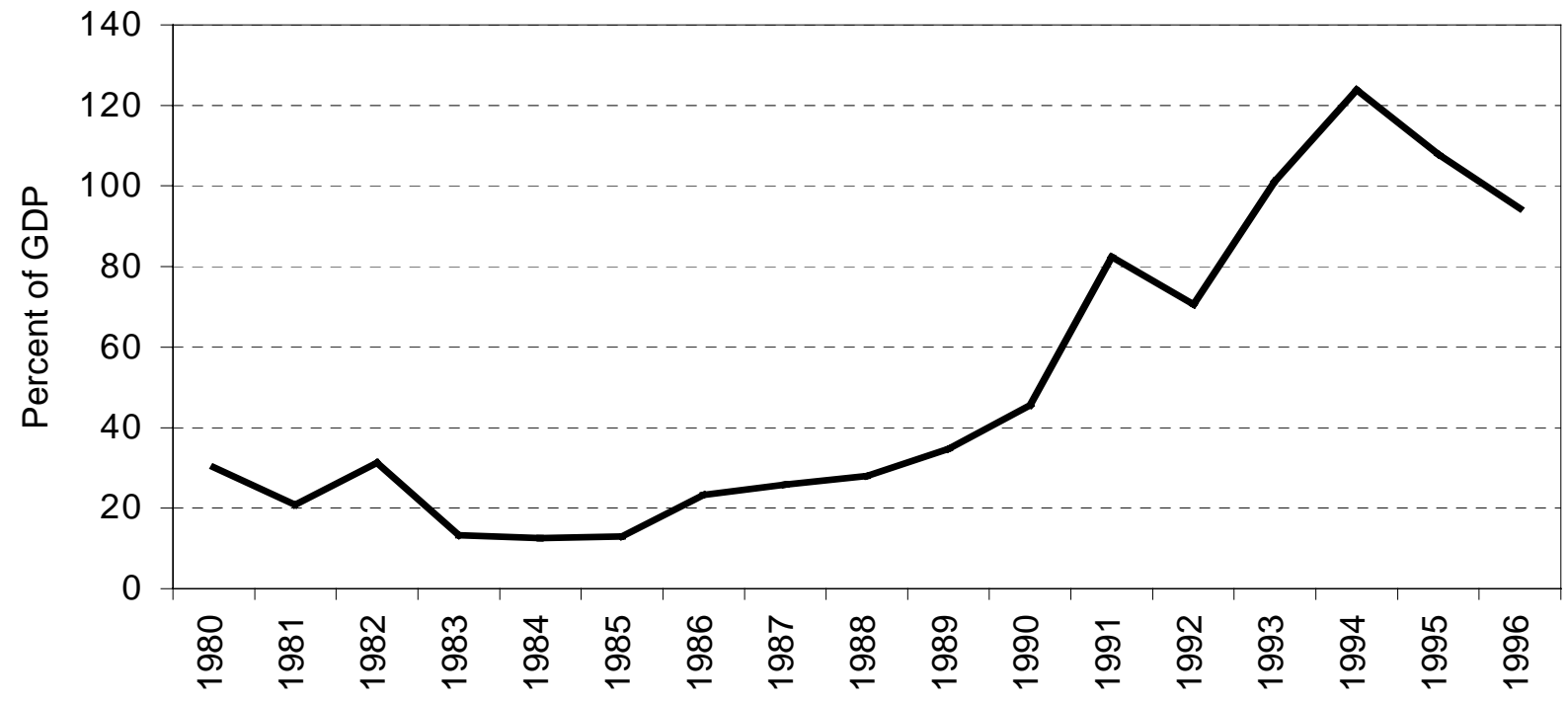

